\title{
Pyridine versus Acetonitrile Coordination in Rhodium-N-Heterocyclic Carbene Square-Planar Complexes
}

\author{
${ }_{5}$ Laura Palacios, ${ }^{\ddagger}$ Andrea Di Giuseppe, ${ }^{\ddagger}$ Ricardo Castarlenas, ${ }^{*},{ }^{\ddagger}$ Fernando J. Lahoz, ${ }^{\ddagger}$ Jesús J. Pérez- \\ Torrente, ${ }^{\sharp}$ Luis A. Oro ${ }^{\ddagger},+$
}

Experimental and theoretical studies on the factors that control the coordination chemistry of N-donor ligands in square-planar complexes of type $\mathrm{RhCl}(\mathrm{NHC}) \mathrm{L}^{1} \mathrm{~L}^{2}\left(\mathrm{NHC}=\mathrm{N}\right.$-heterocyclic carbene) are presented. The dinuclear complexes $\left[\mathrm{Rh}(\mu-\mathrm{Cl})(\mathrm{IPr})\left(\eta^{2} \text {-olefin) }\right]_{2}\right.$ $10\{\operatorname{IPr}=1,3$-bis-(2,6-diisopropylphenyl)imidazol-2-carbene $\}$, have been reacted with different combinations of ligands including pyridine, acetonitrile, 2-pyridylacetonitrile, triphenylphosphine, tricyclohexylphosphine, carbon monoxide or molecular oxygen. In addition, the reactivity of $\mathrm{RhCl}(\mathrm{IPr})\left(\mathrm{PPh}_{3}\right)_{2}$ has also been studied. Pyridine preferentially coordinates trans to the carbene ligand whereas $\pi$-acceptor ligands (olefin, $\mathrm{CO}$ or $\mathrm{PPh}_{3}$ ) are prone to bind cis to IPr and trans to chlorido, unless steric bulk hinders the coordination of the ligand $\left(\mathrm{PCy}_{3}\right)$. In contrast, acetonitrile is more labile than pyridine but it is able to form complexes coordinated cis-to IPr. Molecular dioxygen 15 also displaces the labile cyclooctene ligand in $\operatorname{RhCl}(\operatorname{IPr})\left(\eta^{2}\right.$-coe)(py) to give a square planar dioxygen adduct which can be transformed into a peroxo derivative by additional coordination of pyridine. Charge Decomposition Analysis (CDA) shows that $\sigma$-donation values are similar for coordination at cis- or trans-IPr positions, whereas efficient $\pi$-backbonding is significantly observed at cis position being the favoured coordination site for $\pi$-acceptor ligands. The Rh-IPr rotational barrier in a series of square-planar complexes has been analysed. It has been found that main contribution is the steric hindrance of the ancillary ligand. The presence of a $\pi$-donor ligand such as chlorido 20 slows down the dynamic process.

\section{Introduction}

Catalytic efficiency for a specific transition-metal mediated transformation requires the appropriate choice of a particular set ${ }_{25}$ of ligands that determine the catalytic outcome. ${ }^{1}$ Therefore, a detailed study of coordination chemistry within intermediate species is essential in order to a rational design of active and selective catalysts. ${ }^{2}$ Commonly, organometallic catalysts bear a primary ligand, such as cyclopentadienyl, phosphine, alkylidene,

30 porphyrin, salen, etc, that accounts for the main catalytic properties, whereas ancillary ligands or additives frequently tune the activity or selectivity in a subtle way. This principal ligand may, in certain cases, modulate the position and tightness of ancillary ligands and substrates, thus exerting critical influence 35 over the catalytic results. N-heterocyclic carbenes $(\mathrm{NHCs})^{3}$ belong to this class of ligands due to their particular donoracceptor properties ${ }^{4}$ and high steric hindrance ${ }^{5}$ (Chart 1).

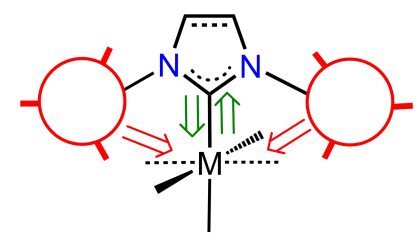

Chart 1. Steric and electronic influence of NHC ligands.
40 An outstanding example of this NHC ligand-management effect has been recently discovered in our laboratories. ${ }^{6}$ Addition of pyridine to the alkyne hydrothiolation ${ }^{7}$ catalysts $[\operatorname{Rh}(\mu$ $\mathrm{Cl})(\mathrm{NHC})\left(\eta^{2} \text {-olefin) }\right]_{2}$, dramatically switches the regioselectivity to the formation of branched vinyl sulfides. It has been 45 demonstrated that pyridine coordination trans to the NHC ligand in the key hydride-thiolate catalytic intermediate species, directs the coordination of the alkyne cis to the carbene ligand. The higher trans-influence of the hydride ligand paves the way to a cis thiolate-alkyne disposition, thereby favouring thiolate 50 insertion. It has been found that subtle modifications on the pyridine motif significantly accounts for the selectivity, similar to other pyridine-modulated catalytic transformations. ${ }^{8}$ In contrast, the addition of other typical $\mathrm{N}$-donor additives such as acetonitrile do not affect the selectivity as much as pyridine ${ }_{55}$ does, ${ }^{9}$ more likely due to the different coordination capability. Particularly for M-NHC complexes, a clear trend in favour of one of such nitrogenated ligands is not observed and competitive coordination of acetonitrile ${ }^{10}$ or pyridine ${ }^{11}$ depends on a complex interplay between electronic and steric factors. Prompted by these ${ }_{60}$ precedents, we present herein an experimental and theoretical study of the coordination of different $\mathrm{N}$-donor ligands into $\mathrm{Rh}$ NHC square-planar complexes.

\section{Results and Discussion}

Synthesis of pyridine and acetonitrile complexes 
Dinuclear olefin complexes $\left[\mathrm{Rh}(\mu \text {-Cl })(\operatorname{IPr})\left(\eta^{2} \text {-olefin }\right)\right]_{2}$ \{olefin $=$ coe (cyclooctene) (1), ethylene (2) $\} \quad\{\operatorname{IPr}=1,3$-bis- $(2,6-$ diisopropylphenyl)imidazol-2-carbene $\}$ are adequate precursors for the preparation of a wide array of mononuclear complexes 5 bearing varied ligands. ${ }^{12}$ As shown previously in our group, pyridine (py) ligands are able to cleave the chlorido-bridges of $\mathbf{1}$ and 2 to generate mononuclear complexes of type $\operatorname{RhCl}(\operatorname{IPr})\left(\eta^{2}-\right.$ olefin)(py) \{coe (3a), ethylene (3b)\}, although the $\eta^{2}$-olefin was not exchanged even on heating 1 in neat pyridine at $80{ }^{\circ} \mathrm{C}$ for one 10 night. $^{6}$ Now, we have observed that acetonitrile behaves differently. Unexpectedly, the starting materials were recovered unreacted after stirring at room temperature for $3 \mathrm{~h}$ a solution of $\mathbf{1}$ or 2 in a mixture toluene $(2 \mathrm{~mL}) /$ acetonitrile $(2 \mathrm{~mL})$. However, in-situ treatment of toluene- $d_{8}$ samples of $\mathbf{1}$ and $\mathbf{2}$ on an NMR

15 tube scale with an excess of acetonitrile $(100 \mu \mathrm{L})$ showed the presence of two different species depending on the coordinated olefin. In the case of ethylene, the new resonances were ascribed to $\mathrm{RhCl}(\mathrm{IPr})\left(\eta^{2}-\mathrm{CH}_{2}=\mathrm{CH}_{2}\right)\left(\mathrm{CH}_{3} \mathrm{CN}\right)$ (4), resulting from acetonitrile cleavage of the chlorido-bridges of 2 . Complex 4

20 likely reverts to the dinuclear species $\mathbf{2}$ during the isolation process (Scheme 1). ${ }^{13}$ The ${ }^{1} \mathrm{H}$ NMR spectrum of 4 at $-20{ }^{\circ} \mathrm{C}$ showed two doublets at $\delta 2.47$ and $2.33 \mathrm{ppm}\left(J_{\mathrm{H}-\mathrm{H}}=12.3 \mathrm{~Hz}\right)$ for the $\eta^{2}$-olefinic protons and a singlet at $2.15 \mathrm{ppm}$ corresponding to the coordinated acetonitrile molecule. The spectrum at room 25 temperature showed a broadening of ethylene and IPr signals indicating a rotational process for both ligands, but unfortunately the activation parameters could not be determined. ${ }^{12 \mathrm{~h}}$ The more noticeable signals in the ${ }^{13} \mathrm{C}\left\{{ }^{1} \mathrm{H}\right\}$-APT NMR spectrum are two doublets at $\delta 181.4 \mathrm{ppm}\left(J_{\mathrm{C}-\mathrm{Rh}}=56.7 \mathrm{~Hz}\right)$ and $41.8 \mathrm{ppm}\left(J_{\mathrm{C}-\mathrm{Rh}}=\right.$

$3015.4 \mathrm{~Hz}$ ) corresponding to the $\mathrm{IPr}$ and ethylene ligands. In contrast, addition of acetonitrile to the $\eta^{2}$-coe derivative $\mathbf{1}$ at room temperature gave rise to a new set of signals that grew up after heating at $80^{\circ} \mathrm{C}$ for $5 \mathrm{~h}$ with concomitant appearance of free coe. The new complex was isolated and characterized as the cationic ${ }_{35}$ derivative $\left[\mathrm{Rh}(\mathrm{IPr})\left(\mathrm{CH}_{3} \mathrm{CN}\right)_{3}\right] \mathrm{Cl}(\mathbf{5})$, in which not only coe but chlorido ligands have been replaced by acetonitrile (Scheme 1). The structure of $\mathbf{5}$ was unequivocally unravelled by comparison of the ${ }^{1} \mathrm{H}$ and ${ }^{13} \mathrm{C}\left\{{ }^{1} \mathrm{H}\right\}$ NMR spectra with those of the triflate salt, $\left[\mathrm{Rh}(\operatorname{IPr})\left(\mathrm{CH}_{3} \mathrm{CN}\right)_{3}\right] \mathrm{OTf}$, that has been recently prepared by 40 protonation of $\mathrm{Rh}(\mathrm{acac})(\mathrm{IPr})(\mathrm{coe})$ (acac = acetylacetonate) with triflic acid. ${ }^{12 \mathrm{~h}}$ Interestingly, compound $\mathbf{5}$ was not obtained on heating a solution of an equilibrium mixture of $\mathbf{2}$ and $\mathbf{4}$ in $\mathrm{CD}_{3} \mathrm{CN}$ at $80{ }^{\circ} \mathrm{C}$ for $5 \mathrm{~h}$, which demonstrates the different bond strength of ethylene and coe. ${ }^{14}$ Prolonged reaction times led to 45 decomposition of the sample.

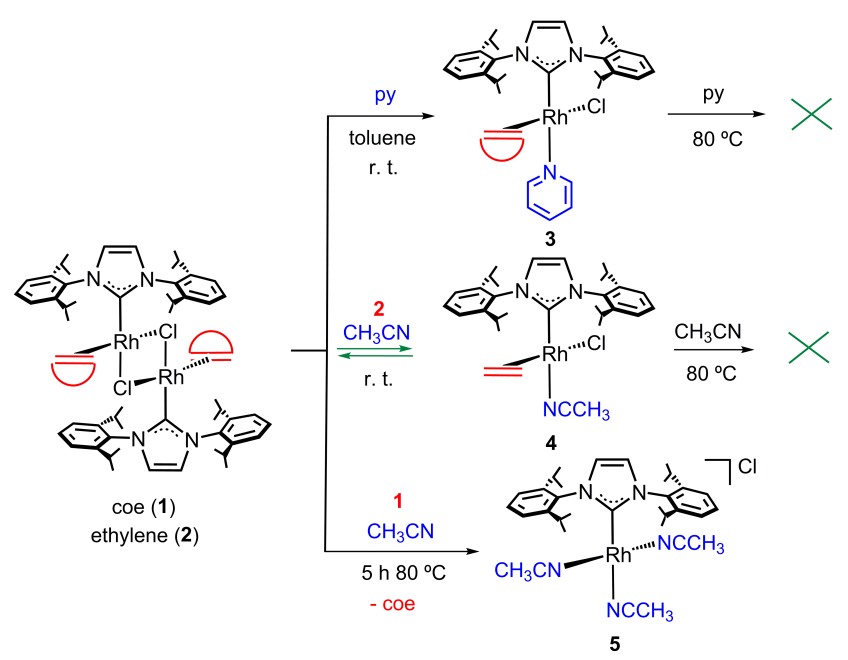

Scheme 1. Bridge-cleavage reactions promoted by N-donor ligands.

DFT calculations on the thermodynamic equilibrium for the ${ }_{50}$ exchange reaction between olefin and $\mathrm{N}$-donor ligands in $\mathbf{3}$ and $\mathbf{4}$ were performed (Scheme 2). In accordance with the experimental results, we have found that the formation of putative disubstituted $\mathrm{N}$-donor ligand complexes $\mathrm{RhCl}(\mathrm{IPr})(\mathrm{py})_{2} \quad(\mathbf{6 t}) \quad$ and $\mathrm{RhCl}(\mathrm{IPr})\left(\mathrm{CH}_{3} \mathrm{CN}\right)_{2}(\mathbf{7 t})$ is disfavoured by an average of 16.4 55 (coe) and 13.0 (ethylene) kcal $\mathrm{mol}^{-1}$. Certainly, the higher $\pi$ acceptor capacity of the olefin with regard to pyridine or acetonitrile may be determinant in the stability of these electronrich $\mathrm{Rh}^{\mathrm{I}}$ derivatives.

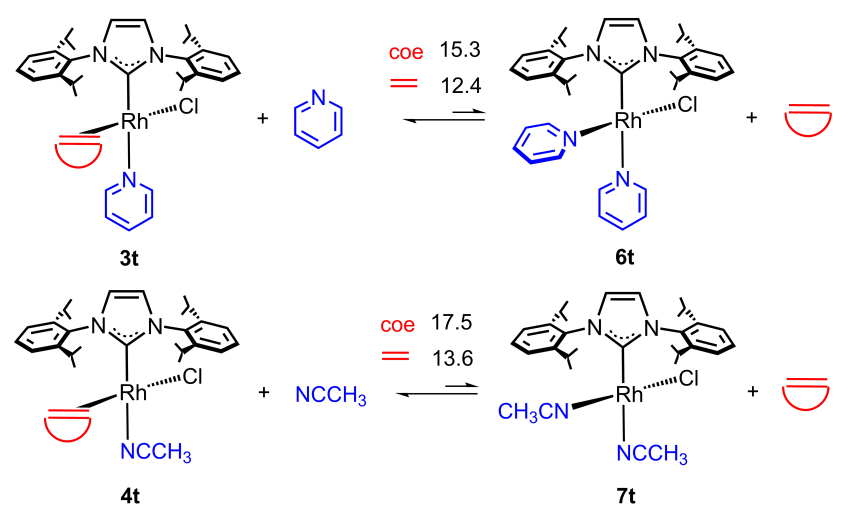

${ }_{60}$ Scheme 2. DFT calculated $\Delta \mathrm{E} \quad\left(\mathrm{kcal} \mathrm{mol}^{-1}\right)$ for the thermodynamic equilibrium between coordinated olefin and pyridine or acetonitrile.

In order to further compare the pyridine and acetonitrile coordination capabilities, complexes $\mathbf{1}$ and $\mathbf{2}$ were treated with 2${ }_{65}$ pyridylacetonitrile. At room temperature, the chloride-bridges were cleaved to give rise to the mononuclear complexes $\mathrm{RhCl}(\mathrm{IPr})\left(\eta^{2}\right.$-olefin $)\left\{\kappa-N,\left(\mathrm{NC}_{5} \mathrm{H}_{4}\right)-2-\mathrm{CH}_{2} \mathrm{CN}\right\} \quad\{$ coe $=(\mathbf{8}) ;$ ethylene $(\mathbf{9})\}$, bearing the pyridine moiety coordinated to the metal center and a free nitrile group (Scheme 3). No chelate or 70 dinuclear species were observed. Coordination of a second equivalent of 2-pyridylacetonitrile was observed on heating 8 at $80{ }^{\circ} \mathrm{C}$ for $3 \mathrm{~h}$. A new orange complex $\mathrm{RhCl}(\mathrm{IPr})\left\{\kappa-\mathrm{N},\left(\mathrm{NC}_{5} \mathrm{H}_{4}\right)-2-\right.$ 
$\left.\mathrm{CH}_{2} \mathrm{CN}\right\}\left\{\kappa-N, \mathrm{NCCH}_{2}-2-\left(\mathrm{C}_{5} \mathrm{H}_{4} \mathrm{~N}\right)\right\} \quad(\mathbf{1 0})$ was isolated in $72 \%$ yield, resulting from the replacement of coe by a 2pyridylacetonitrile ligand which is coordinated through the nitrogen atom of the nitrile group. No other products were 5 apparent on the NMR spectra.

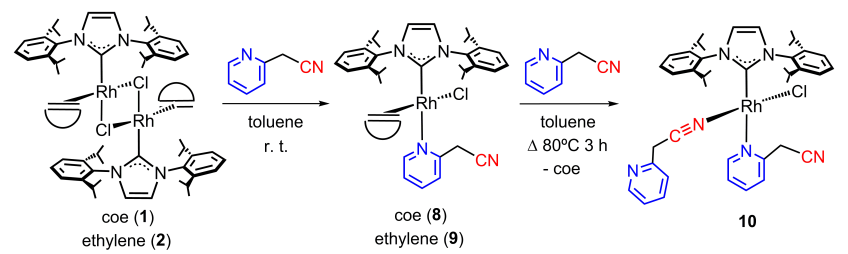

Scheme 3. Preparation of 2-pyridylacetonitrile rhodium complexes.

Complex 8 was characterized by X-ray diffraction analysis. 10 The molecular structure is displayed in figure 1 . The mode of coordination of the N-donor ligand was corroborated in the solid state. The metallic center presents a distorted square-planar geometry with the nitrogenated ligand located trans to the IPr $\left\{\mathrm{C}(1)-\mathrm{Rh}-\mathrm{N}(3)=167.35(7)^{\circ}\right\}$. The rhodium-carbon separation $15[\mathrm{Rh}-\mathrm{C}(1)=1.9835(18) \AA]$ compares well with previously reported Rh-NHC bond distances. ${ }^{3 \mathrm{c}, 12}$ Either the wingtips of the IPr, coe or pyridylacetonitrile ligands adopt an out-of-plane disposition from the square-planar metal environment.

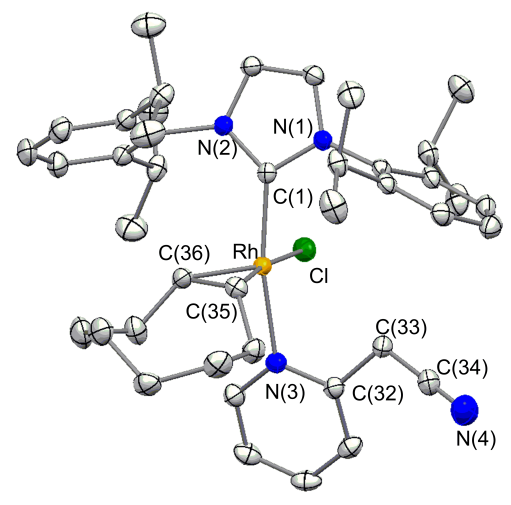

20 Figure 1. Molecular diagram for 8. Selected bond lengths $(\AA)$ and angles $\left({ }^{\circ}\right)$ : $\mathrm{Rh}-\mathrm{C}(1)=1.9835(18)$, Rh-N(3) = 2.1329(16); Rh$\mathrm{C}(35)=2.1383(19), \mathrm{Rh}-\mathrm{C}(36)=2.1066(19), \mathrm{C}(35)-\mathrm{C}(36)=$ 1.402(3); $\mathrm{C}(1)-\mathrm{Rh}-\mathrm{N}(3)=167.35(7), \mathrm{C}(1)-\mathrm{Rh}-\mathrm{C}(35)=95.19(7)$, $\mathrm{C}(1)-\mathrm{Rh}-\mathrm{C}(36)=94.47(8), \mathrm{C}(1)-\mathrm{Rh}-\mathrm{Cl}=88.27(5)$.

${ }_{25}$ The ${ }^{1} \mathrm{H}$ and ${ }^{13} \mathrm{C}\left\{{ }^{1} \mathrm{H}\right\}$ NMR spectra of $\mathbf{8}$ and $\mathbf{9}$ are consistent with the structure shown in figure 1 . The presence of a substituent in the 2-position of the pyridine ligand hinders rotation of both $\mathrm{IPr}^{15}$ and 2-pyridylacetonitrile ligands resulting in an asymmetric molecule. Thus, four and eight signals were observed respectively 30 for the $\mathrm{CH}$ and $\mathrm{CH}_{3}$ isopropyl-IPr substituents. The four inequivalent protons of coordinated ethylene in $\mathbf{9}$ appeared as doublet of doublets at $2.63,2.22,1.91$, and $1.37 \mathrm{ppm}$ with homonuclear couplings of 11.3 and $8.2 \mathrm{~Hz}$. Notably, the diastereotopic methylene protons of the dangling nitrile group 35 were observed as doublets at $\delta 5.79$ and $3.76 \mathrm{ppm},\left(J_{\mathrm{H}-\mathrm{H}}=20.0\right.$ $\mathrm{Hz})$ for 8 or 4.97 and $3.98 \mathrm{ppm}\left(J_{\mathrm{H}-\mathrm{H}}=20.1 \mathrm{~Hz}\right)$ for $\mathbf{9}$. In the
${ }^{13} \mathrm{C}\left\{{ }^{1} \mathrm{H}\right\}$-APT NMR spectra, the resonances assigned to carbon atoms directly bonded to rhodium appeared as doublets around $183 \mathrm{ppm}\left(J_{\mathrm{C}-\mathrm{Rh}}=54 \mathrm{~Hz}\right)$ for $\mathrm{IPr}, 60.0\left(J_{\mathrm{C}-\mathrm{Rh}}=16.6 \mathrm{~Hz}\right)$ and 52.8 ${ }_{40} \mathrm{ppm}\left(J_{\mathrm{C}-\mathrm{Rh}}=14.1 \mathrm{~Hz}\right)$ for coe and $44.8\left(J_{\mathrm{C}-\mathrm{Rh}}=17.6 \mathrm{~Hz}\right)$ and 37.4 $\operatorname{ppm}\left(J_{\mathrm{C}-\mathrm{Rh}}=15.8 \mathrm{~Hz}\right)$ for ethylene. The ${ }^{1} \mathrm{H}-{ }^{15} \mathrm{~N} \mathrm{HMBC}$ spectrum of 8 confirmed the coordination of the pyridine motif, $\delta 270.5 \mathrm{vs}$ $315.2 \mathrm{ppm}$ for the free 2-pyridylacetonitrile. ${ }^{12 \mathrm{i}}$

The proposed structure for complex $\mathbf{1 0}$ was supported by NMR ${ }_{45}$ spectra. The ${ }^{1} \mathrm{H}$ spectrum displayed two sets of signals for both methylene groups of either $\mathrm{N}$-donor ligand, one broad signal at $3.32 \mathrm{ppm}$ integrating for two protons and two doublets at 2.75 and $2.67 \mathrm{ppm}$ each integrating for one proton. Similarly to 8 and 9, the two doublet resonances were ascribed to a $\kappa$-N,pyridine so coordinated trans to IPr, whereas the broad resonance corresponds to a 2-pyridylacetonitrile ligand coordinated through the nitrile moiety in cis position to $\operatorname{IPr}^{16}$ In fact, a dynamic behaviour with the nitrogenated molecule in solution can be inferred from the ${ }^{1} \mathrm{H}^{15} \mathrm{~N}$ HMBC spectrum. The signal ${ }_{55}$ corresponding to nitrogen atom of the pyridine appears at $\delta 315.6$ $\mathrm{ppm}$, close to the free ligand value, whereas the nitrile-nitrogen atom resonates at $241.9 \mathrm{ppm}$, with a deviation of $12 \mathrm{ppm}$ high field shifted indicating coordination to metal centre. In addition, the ${ }^{13} \mathrm{C}\left\{{ }^{1} \mathrm{H}\right\}$-APT NMR spectrum displays just one deshielded ${ }_{60}$ doublet at $168.9 \mathrm{ppm}$ with $J_{\mathrm{C}-\mathrm{Rh}}=50.5 \mathrm{~Hz}$, corresponding to the IPr ligand and two set of carbon atoms for each pyridylacetonitrile ligands. Moreover, an NMR sample of $\mathbf{1 0}$ in $\mathrm{CD}_{3} \mathrm{CN}$ showed the disappearance of the signals corresponding to the $\kappa-N$,cyano ligand and not those of the $\kappa-N$,pyridine group, ${ }_{65}$ while resonances corresponding to free 2-pyridylacetonitrile emerged due to an exchange process with the deuterated solvent.

\section{Preparation of phosphine complexes}

The observed coordination preference of $\mathrm{N}$-donor ligands to bulky NHC-rhodium-chlorido square-planar complexes may arise 70 from electronic or steric factors. Thus, comparison with other ubiquitous ligands in organometallic catalysis as triphenylphosphine was undertaken. Treatment of $\mathrm{RhCl}(\mathrm{IPr})\left(\mathrm{PPh}_{3}\right)_{2}$ (11) with pyridine at room temperature for 20 min led to the formation of $\mathrm{RhCl}(\operatorname{IPr})\left(\mathrm{PPh}_{3}\right)(\mathrm{py})$ (12), by 75 phosphine-pyridine exchange, ${ }^{17}$ which was isolated as a yellow solid in $83 \%$ yield (Scheme 4). In a similar way to the observed for the dinuclear complexes 1-2, only the phosphine trans to IPr was replaced by pyridine, even when neat pyridine was used as solvent.

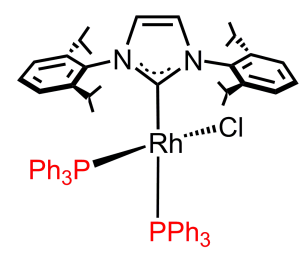

11

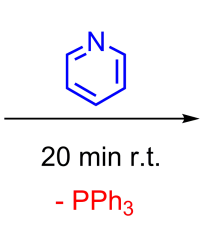

$-\mathrm{PPh}_{3}$
80

Scheme 4. Pyridine-phosphine exchange reaction leading to $\mathrm{RhCl}(\mathrm{IPr})\left(\mathrm{PPh}_{3}\right)$ (py) (12).

Single crystals of $\mathbf{1 2}$ were obtained by slow diffusion of $n$ hexane over a saturated toluene solution of the compound. A 
view of the molecular structure is depicted in Figure 2. Similarly to $\mathbf{8}$, the metal in $\mathbf{1 2}$ presents a distorted square-planar geometry with the pyridine located trans to the $\operatorname{IPr}\{\mathrm{C}(1)-\mathrm{Rh}-\mathrm{N}(3)=$ $\left.172.19(7)^{\circ}\right\}$ and a rhodium-carbon separation of 1.9761(19) Å. A 5 significative $\pi-\pi$ stacking between the pyridine ligand and a phenyl group was evident from the structural data (centroidcentroid distance $3.656 \AA$; dihedral angle between planes $20.2^{\circ}$ ) with potential implications both on structure stability and on fluxional (rotational) behaviour.

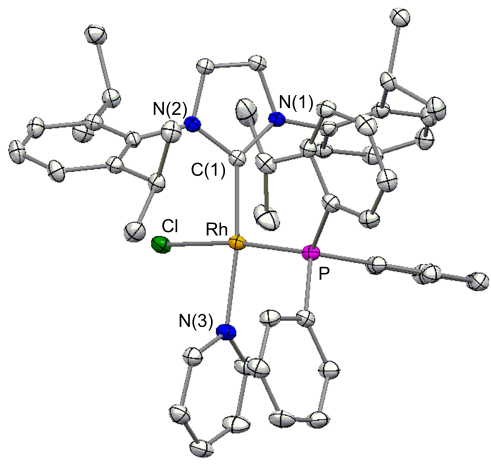

Figure 2. Molecular diagram for 12. Selected bond lengths $(\AA)$ and angles $\left({ }^{\circ}\right)$ : Rh-C $(1)=1.9761(19), \mathrm{Rh}-\mathrm{N}(3)=2.1089(17)$, Rh$\mathrm{P}=2.2124(6) ; \mathrm{C}(1)-\mathrm{Rh}-\mathrm{N}(3)=172.19(7), \mathrm{C}(1)-\mathrm{Rh}-\mathrm{P}=98.22(6)$, $\mathrm{N}(3)-\mathrm{Rh}-\mathrm{P}=89.29(5), \mathrm{Cl}-\mathrm{Rh}-\mathrm{P}=172.24(2)$.

15 The NMR data for $\mathbf{1 2}$ in $\mathrm{C}_{6} \mathrm{D}_{6}$ are in agreement with the structure observed in the solid state. The ${ }^{31} \mathrm{P}\left\{{ }^{1} \mathrm{H}\right\}$ NMR spectrum displays a doublet at $\delta 45.3 \mathrm{ppm}$ with a $J_{\mathrm{P}-\mathrm{Rh}}=222.0 \mathrm{~Hz}$, typical for a trans chlorido-phosphine complex, ${ }^{12 a}$ whereas the $\operatorname{IPr}$ carbon atom shows in the ${ }^{13} \mathrm{C}\left\{{ }^{1} \mathrm{H}\right\}$ NMR spectrum a small C-P

20 coupling of $15.6 \mathrm{~Hz}$ in accordance with a cis carbene-phosphine disposition.

The coordination of the bulky triphenylphosphine ligand cis to the hindered IPr in $\mathbf{1 2}$ is rather surprising. The high trans-effect of the IPr ligand should promote the exchange of the trans 25 phosphine in 11, thus favouring kinetically the isomer observed for 12. However, this configuration is also thermodynamically favoured as no isomerization was observed on heating a sample of 12 at $60^{\circ} \mathrm{C}$ for $2 \mathrm{~h}$. DFT calculations on the ground state are in accordance with experimental results (Figure 3). Isomer 12at 30 with the pyridine located trans to $\operatorname{IPr}^{18}$ is 5.4 and $5.8 \mathrm{kcal} \mathrm{mol}^{-1}$ more stable than those with $\mathrm{PPh}_{3}(\mathbf{1 2 b t})$ and chlorido ${ }^{19}$ (12ct) in that position. In this case, in contrast to that observed for 2 pyridylacetonitrile coordination in $\mathbf{1 0}$, both phosphine and pyridine suffer from steric hindrance when located cis to the 35 bulky IPr, thus, a rational explanation for the preference of $\mathrm{PPh}_{3}$ to coordinate $c i$ s to IPr should be its slightly higher $\pi$-acceptor capacity with regard to pyridine. ${ }^{20}$
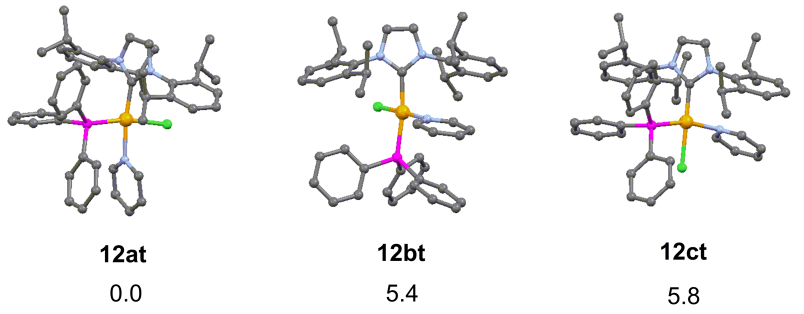

Figure 3. DFT-computed energies for the possible stereoisomers ${ }_{40}$ of $12\left(\Delta \mathrm{E}, \mathrm{kcal} \mathrm{mol}^{-1}\right)$.

Acetonitrile behaves in a different way than pyridine does. Treatment of $\mathbf{1 1}$ with acetonitrile at room temperature resulted in the isolation of the starting material, similarly to that observed for $\mathbf{1}$ and 2. However, a sample of $\mathbf{1 1}$ dissolved in $\mathrm{CD}_{3} \mathrm{CN}$ led to the 45 in-situ formation of two isomers of the complex $\mathrm{RhCl}(\mathrm{IPr})\left(\mathrm{PPh}_{3}\right)\left(\mathrm{CD}_{3} \mathrm{CN}\right)(\mathbf{1 3})$ in a 70:30 ratio (Scheme 5). ${ }^{21}$ The ${ }^{31} \mathrm{P}\left\{{ }^{1} \mathrm{H}\right\}$ NMR spectrum displays, in addition to a signal corresponding to free $\mathrm{PPh}_{3}$, two new doublets at 41.9 and 22.3 ppm with $J_{\mathrm{P}-\mathrm{Rh}}$ of 206.7 and $89.4 \mathrm{~Hz}$, respectively. In accordance 50 with that observed for phosphine-pyridine complex 12, the derivative with the highest rhodium-phosphine scalar coupling was ascribed to the isomer having a cis IPr-phosphine configuration (13a), whereas the minor isomer presented trans IPr-phosphine disposition (13b). Complex 13a seems to be ${ }_{55}$ kinetically favoured over $\mathbf{1 3 b}$. A $\mathrm{CD}_{3} \mathrm{CN}$ solution of $\mathbf{1 2}$ showed the exclusive formation of 13a resulting from the pyridine/acetonitrile exchange. Heating the sample at $60{ }^{\circ} \mathrm{C}$ for $48 \mathrm{~h}$ gave rise to the formation of a new cationic bis-acetonitrile complex $\left[\mathrm{Rh}(\mathrm{IPr})\left(\mathrm{PPh}_{3}\right)\left(\mathrm{CH}_{3} \mathrm{CN}\right)_{2}\right] \mathrm{Cl}$ (14), with a phosphine60 carbene trans disposition (Figure 4). The same complex was obtained on heating a mixture of 13a and 13b arising from 11. The stabilization gained from a mutually trans disposition of acetonitrile ligands in $\mathbf{1 4}$ would likely account for the formation of only one isomer with phosphine-carbene trans configuration.

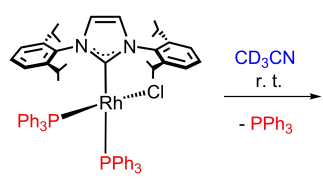

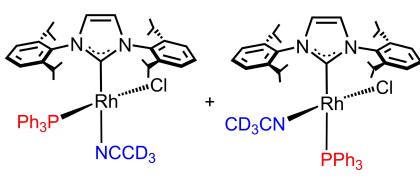

$13 a \cdot 70 \%$

$13 \mathrm{~b} \cdot 30 \%$
$\mathrm{CD}_{3} \mathrm{CN} \backslash 2 \mathrm{~h}, 60^{\circ} \mathrm{C}$

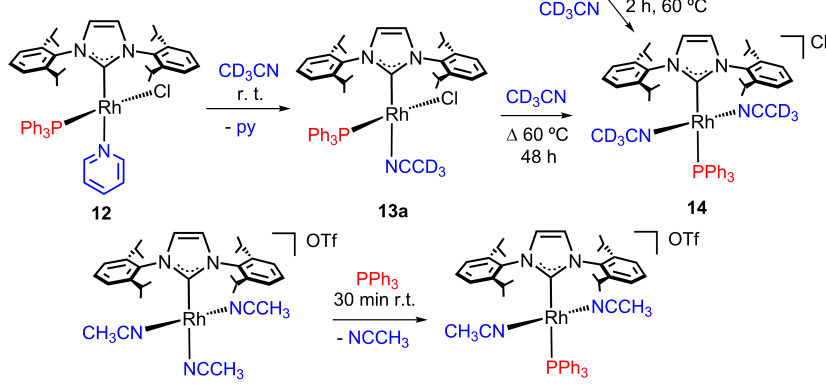

15
Scheme 5. Formation of rhodium-phosphine-acetonitrile complexes. 


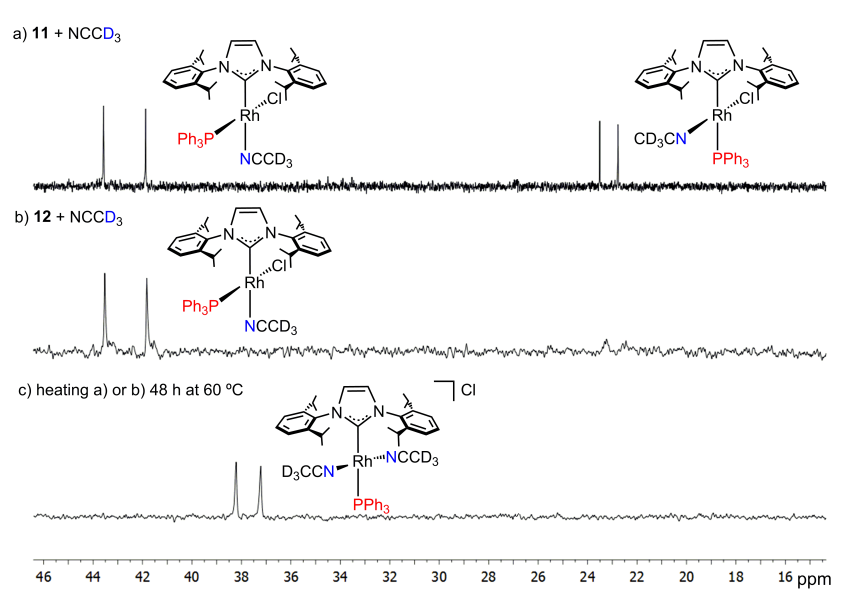

Figure $4 .{ }^{31} \mathrm{P}\left\{{ }^{1} \mathrm{H}\right\}$ NMR spectra of $\mathbf{1 3}$ and $\mathbf{1 4}$.

The triflate (OTf) salt of 14, $\left[\mathrm{Rh}(\mathrm{IPr})\left(\mathrm{PPh}_{3}\right)\left(\mathrm{CH}_{3} \mathrm{CN}\right)_{2}\right] \mathrm{OTf}$ (15), has been independently prepared by treatment of the 5 cationic derivative $\left[\mathrm{Rh}(\mathrm{IPr})\left(\mathrm{CH}_{3} \mathrm{CN}\right)_{3}\right] \mathrm{OTf}{ }^{12 \mathrm{~h}}$ with $\mathrm{PPh}_{3}$. The more noticeable features of the NMR spectra of $\mathbf{1 5}$ are the doublet at $\delta 37.1 \mathrm{ppm}$ with a $J_{\mathrm{P}-\mathrm{Rh}}$ of $120.7 \mathrm{~Hz}$ in the ${ }^{31} \mathrm{P}\left\{{ }^{1} \mathrm{H}\right\}$ NMR spectrum, and the resonance at $\delta 185.3 \mathrm{ppm}\left(\mathrm{dd}, J_{\mathrm{C}-\mathrm{P}}\right.$ of $114.6 \mathrm{~Hz}$, and $J_{\mathrm{C}-\mathrm{Rh}}$ of $46.5 \mathrm{~Hz}$ ) in the ${ }^{13} \mathrm{C}\left\{{ }^{1} \mathrm{H}\right\}$ for the carbene 10 carbon atom indicating a trans IPr-phosphine configuration. DFT calculations on the ground state of $\mathbf{1 3}$ show that, in contrast to that observed for pyridine-phosphine isomers of 12, both isomers of $\mathbf{1 3}$ present very similar computed energies (Figure 5).

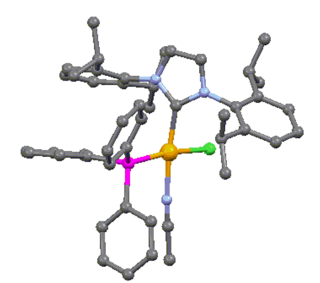

13at

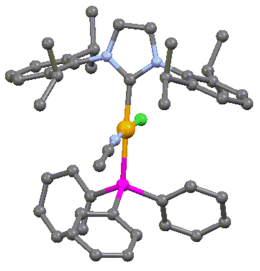

$13 \mathrm{bt}$
15 Figure 5. DFT-computed energies for possible stereoisomers of $13\left(\Delta \mathrm{E}, \mathrm{kcal} \mathrm{mol}^{-1}\right)$.

In contrast to the behaviour observed for complexes containing $\mathrm{PPh}_{3}$ ligands, treatment of $\mathrm{Rh}^{\mathrm{I}}-\mathrm{NHC}$ dimer 1 with a bulkier and more electron-rich phosphine such as tricyclohexylphosphine $20\left(\mathrm{PCy}_{3}\right)$ in $\mathrm{N}$-donor solvents led to different results (Scheme 6). The phosphine did not incorporate into the metallic complex in pyridine solutions at $60{ }^{\circ} \mathrm{C}$ for one night and pure Rh-NHCpyridine complex 3a was isolated. However, a new NHCphosphine complex $\mathrm{RhCl}(\mathrm{IPr})\left(\mathrm{PCy}_{3}\right)\left(\mathrm{CH}_{3} \mathrm{CN}\right)$ (16) was obtained ${ }_{25}$ from acetonitrile solutions after $30 \mathrm{~min}$ at $60{ }^{\circ} \mathrm{C}$. The ${ }^{31} \mathrm{P}\left\{{ }^{1} \mathrm{H}\right\}$ NMR spectrum in $\mathrm{CD}_{3} \mathrm{CN}$ of $\mathbf{1 6}$ displays a doublet at $\delta 34.6 \mathrm{ppm}$ with $J_{\mathrm{P}-\mathrm{Rh}}$ of $118.8 \mathrm{~Hz}$, indicating a trans NHC-phosphine disposition. Moreover, the carbene carbon atom resonates in the in the ${ }^{13} \mathrm{C}\left\{{ }^{1} \mathrm{H}\right\}$-APT NMR spectrum as a doublet of doublets at $\delta$ 30 $188.8 \mathrm{ppm}$ with typical couplings $J_{\mathrm{C}-\mathrm{Rh}}$ of $44.3 \mathrm{~Hz}$ and $J_{\mathrm{C}-\mathrm{P}}$ of
106.9 Hz, corroborating the proposed configuration. These results can be rationalized assuming the high steric encumbrance of $\mathrm{PCy}_{3}$ and the affinity of pyridine for trans-to-IPr coordination.

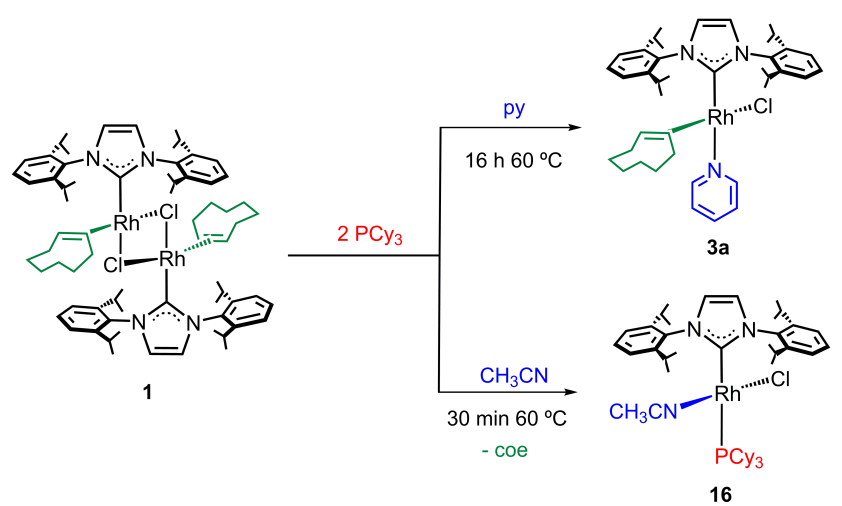

${ }_{35}$ Scheme 6. Reactivity of $\mathbf{1}$ with $\mathrm{PCy}_{3}$ in different nitrogenated solvents.

\section{Coordination of small molecules}

In order to broaden the study of the effect of IPr over coordination of the ancillary ligands in square-planar $\mathrm{Rh}^{\mathrm{I}}$ 40 complexes, the reactivity with small molecules such as $\mathrm{CO}$ and dioxygen was also investigated. Treatment of $\mathbf{1}$ or $\mathbf{3 a}$ with $\mathrm{CO}$ in pyridine as solvent at room temperature led to the formation of $\mathrm{RhCl}(\mathrm{IPr})(\mathrm{CO})(\mathrm{py})$ (17) (Scheme 7). In contrast, bubbling carbon monoxide through a solution of $\mathbf{1}$ in acetonitrile led to the ${ }_{45}$ isolation of the bis-carbonyl complex $\mathrm{RhCl}(\mathrm{IPr})(\mathrm{CO})_{2} .{ }^{12 \mathrm{~b}}$ The coordination of pyridine trans to IPr of $\mathbf{1 7}$ was substantiated by the high $J_{\mathrm{C}-\mathrm{Rh}}$ coupling constant $(82.0 \mathrm{~Hz})$ displayed for the $\mathrm{CO}$ carbon atom in the ${ }^{13} \mathrm{C}\left\{{ }^{1} \mathrm{H}\right\}$ NMR spectrum, which is typical for a mutually trans chlorido-CO disposition. ${ }^{22}{ }^{1} \mathrm{H}$ VT-NMR spectra of so 17 in $\mathrm{CD}_{2} \mathrm{Cl}_{2}$, showed a dynamic behaviour as result of carbene rotation around the $\mathrm{Rh}-\mathrm{IPr}$ bond (Figure 6). ${ }^{15}$ The activation parameters obtained from the corresponding Eyring analysis were $\Delta H^{*}=10.6 \pm 0.3 \mathrm{kcal} \cdot \mathrm{mol}^{-1}$ and $\Delta S^{*}=0.2 \pm 0.6 \mathrm{cal} \cdot \mathrm{K}^{-1} \mathrm{~mol}^{-1}$ which lay in the range of those previously reported for $\mathrm{Rh}-\mathrm{IPr}$ ${ }_{55}$ complexes. ${ }^{6,12 \mathrm{~h}, 15}$

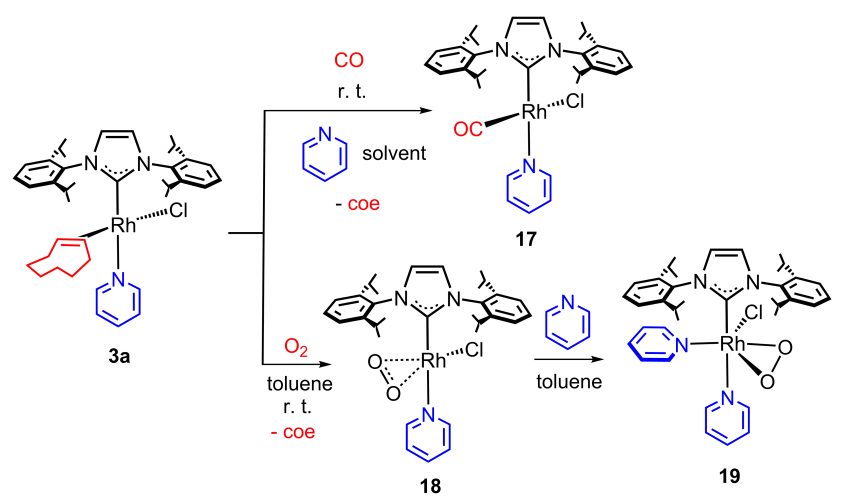

Scheme 7. Reactivity of $\mathbf{3 a}$ with small molecules. 


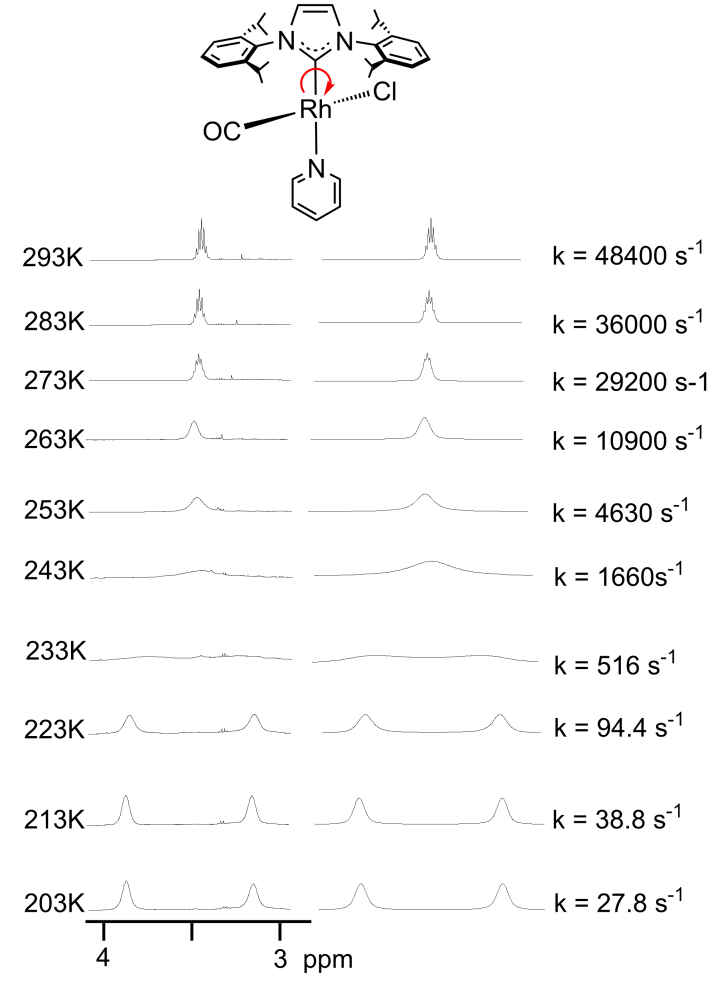

Figure 6. Variable temperature NMR spectra of 17 in $\mathrm{CD}_{2} \mathrm{Cl}_{2}$ showing the coalescence of the $\mathrm{CH}$-isopropyl (IPr): experimental (left) and calculated (right).

5 Complex 3a reacts very fast with molecular oxygen. Bubbling air through a toluene solution of 3a for $15 \mathrm{~min}$ at room temperature resulted in the formation of complex $\mathrm{RhCl}(\mathrm{IPr})\left(\mathrm{O}_{2}\right)$ (py) (18), that was isolated as a green solid in $70 \%$ yield. Prolonged reaction times under air gave rise to unidentified ${ }_{10}$ products, as previously described by the Crudden's group. ${ }^{12 \mathrm{f}} \mathrm{We}$ were not able to isolate any clean complex from the similar treatment of $\mathbf{1}$ in acetonitrile solutions. Addition of pyridine to $\mathbf{1 8}$ led to the formation of the bis-pyridine adduct $\mathrm{RhCl}(\mathrm{IPr})\left(\mathrm{O}_{2}\right)(\mathrm{py})_{2}$ (19) which was isolated as a yellow solid in $75 \%$ yield. The 15 coordination of dioxygen to transition metal complexes very often results in the formation of monodentated dioxygen adducts $\left\{\mathrm{O}_{2}\right\}$ or peroxo $\left\{\mathrm{O}_{2}{ }^{2-}\right\}$ complexes. ${ }^{23}$ In this particular case, complex $\mathbf{1 8}$ is better described as a tetracoordinated $\mathrm{Rh}^{\mathrm{I}}\left\{\mathrm{O}_{2}\right\}^{24}$ species whereas 19 points to a $\mathrm{Rh}^{\mathrm{III}}\left\{\mathrm{O}_{2}{ }^{2-}\right\}^{25}$ hexacoordinated 20 compound. Suitable single crystals for X-ray determination were obtained by slow diffusion of $n$-hexane into saturated toluene solutions of $\mathbf{1 8}$ and 19. A diagram of the molecular structures is shown in figure 7 .
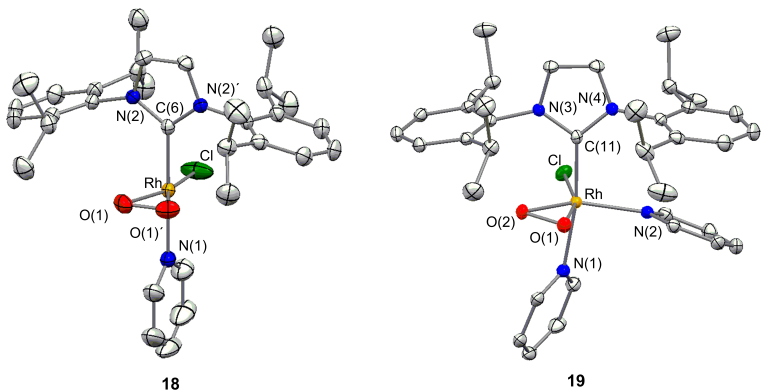

${ }_{25}$ Figure 7. Molecular diagram for 18 and 19. Selected bond lengths $(\AA)$ and angles $\left({ }^{\circ}\right)$, 18: $\mathrm{Rh}-\mathrm{C}(6)=1.984(3)$, Rh-O $(1)=$ 1.959(5), Rh-N(1) = 2.146(3), O(1)-O(1)' = 1.424(11), Rh-Cl = 2.287(2); $\mathrm{C}(6)-\mathrm{Rh}-\mathrm{N}(1)=178.33(12), \mathrm{O}(1)-\mathrm{Rh}-\mathrm{O}^{\prime}(1)=42.6(3)$, $\mathrm{O}(1)-\mathrm{Rh}-\mathrm{N}(1)=88.73(17)$; 19: Rh-C (11) = 2.0081(17), Rh-O(1) ${ }_{30}=1.9884(12), \mathrm{Rh}-\mathrm{O}(2)=1.9819(13), \mathrm{Rh}-\mathrm{N}(1)=2.1541(15), \mathrm{Rh}-$ $\mathrm{N}(2)=2.1462(15), \mathrm{O}(1)-\mathrm{O}(2)=1.4399(17), \mathrm{Rh}-\mathrm{Cl}=2.4057(4)$; $\mathrm{C}(11)-\mathrm{Rh}-\mathrm{N}(1)=170.67(6), \mathrm{C}(11)-\mathrm{Rh}-\mathrm{N}(2)=101.44(6), \mathrm{O}(1)-$ $\mathrm{Rh}-\mathrm{O}(2)=42.53(5), \mathrm{O}(1)-\mathrm{Rh}-\mathrm{N}(2)=109.33(5), \mathrm{Cl}-\mathrm{Rh}-\mathrm{O}(2)=$ 118.83(4), N(1)-Rh-N(2) = 87.80(6), C(11)-Rh-Cl= 89.37(5).

35 Complex 18 shows a square-planar structure with a carbenepyridine trans disposition $\left\{\mathrm{C}(6)-\mathrm{Rh}-\mathrm{N}(1)=178.33(12)^{\circ}\right\}$, typical of $\mathrm{Rh}^{\mathrm{I}}$ species, whereas compound $\mathbf{1 9}$ is better described as a distorted octahedron with one pyridine ligand trans to $\operatorname{IPr}\{\mathrm{C}(11)$ $\left.\mathrm{Rh}-\mathrm{N}(1)=170.67(6)^{\circ}\right\}$ and the other nitrogenated ligand cis 40 disposed $\left\{\mathrm{C}(11)-\mathrm{Rh}-\mathrm{N}(2)=101.44(6)^{\circ}\right\}$ more characteristic of $\mathrm{Rh}^{\mathrm{III}}$ complexes. The $\mathrm{O}-\mathrm{O}$ distance in $19\{1.4399(17)\}$ lies within the range described for Rh-peroxo complexes (1.43-1.50 $\AA)$. The dioxygen separation in $\mathbf{1 8}\{1.424(11) \AA\}$ is only slightly shorter than that in $\mathbf{1 9}$, with its accuracy affected by the positional 45 disorder of the ligand (see experimental). However, the O-O stretching mode in the IR spectra was observed at $965 \mathrm{~cm}^{-1}$ for $\mathbf{1 8}$ and $879 \mathrm{~cm}^{-1}$ for $\mathbf{1 9}$, which reflects the different character of the dioxygen ligand in both complexes. The formation of the oxidized complex $\mathbf{1 9}$ is likely favoured by the ability of $\mathbf{1 8}$ to 50 easily accommodate a new ligand, a pyridine in this case, changing the coordination mode of the dioxygen molecule.

The NMR spectra of $\mathbf{1 8}$ are in agreement with a IPr-pyridine trans coordination in a $C_{\mathrm{s}}$-symmetric compound. In contrast, the NMR of 19 in $\mathrm{CD}_{2} \mathrm{Cl}_{2}$ showed no equivalent pyridine ligands and ${ }_{55}$ also evidenced the presence of a symmetry plane that makes equivalent two isopropyl groups which points to the ionization of the chlorido ligand in solution to give the $\left[\mathrm{Rh}(\mathrm{IPr})\left(\mathrm{O}_{2}\right)(\mathrm{py})_{2}\right] \mathrm{Cl}$ species. Similarly to $\mathbf{1 7}$, complexes 18 and 19 showed a dynamic behaviour as evidenced in a ${ }^{1} \mathrm{H}$ VT-NMR study due to $\mathrm{IPr}$ 60 rotation. The activation parameters obtained from the corresponding Eyring analysis were $\Delta H^{*}=9.9 \pm 0.6 \mathrm{kcal} \cdot \mathrm{mol}^{-1}$ and $\Delta S^{*}=-4.2 \pm 1.7 \mathrm{cal} \cdot \mathrm{K}^{-1} \mathrm{~mol}^{-1}$ for $\mathbf{1 8}$ and $\Delta H^{*}=13.0 \pm 0.7$. $\mathrm{kcal} \cdot \mathrm{mol}^{-1}$ and $\Delta S^{*}=2.8 \pm 1.5 \mathrm{cal} \cdot \mathrm{K}^{-1} \mathrm{~mol}^{-1}$ for 19 . The rotational barrier for $\mathbf{1 8}$ is the lowest ever calculated for similar ${ }_{65} \mathrm{Rh}^{\mathrm{I}}$-IPr complexes (Table 1). It is generally assumed that the steric hindrance of the auxiliary ligands on the Rh-IPr motif play a fundamental role in the activation barriers for the rotation. ${ }^{15}$ For example, the phosphine complex $\operatorname{RhCl}(\operatorname{IPr})\left(\eta^{2}-\right.$ $\left.\mathrm{CH}_{2}=\mathrm{CH}_{2}\right)\left(\mathrm{PPh}_{3}\right)^{15}$ show the higher value (entry 2, table 1). In 70 addition, $\eta^{2}$-coe complexes have slightly higher values than $\eta^{2}$ ethylene ones (entries 4 vs 5 and 6 vs 7, table 1). Nevertheless, a 
bulky environment is not the sole factor that contributes to the rotational barrier. It has been proposed that the lone pair of electrons of a $\pi$-donor ligand such as chlorido may interact with the empty p-orbital of the $\mathrm{NHC},{ }^{26}$ thus affecting the rotation. In 5 the present case, the chlorido-IPr complex 3a exhibits a higher rotational barrier $\left(15.1 \pm 0.7 \mathrm{kcal} \cdot \mathrm{mol}^{-1}\right.$, entry 4 , table 1$)$ than the acac-IPr complex $\left(12.7 \pm 0.4 \mathrm{kcal} \cdot \mathrm{mol}^{-1}\right.$, entry 6 , table 1$)$ or a cationic free-chlorido derivative $\left(12.7 \pm 0.3 \mathrm{kcal} \cdot \mathrm{mol}^{-} 1\right.$, entry 8 , table 1).

${ }_{10}$ Table 1. Comparison of rotational barriers for various $\mathrm{Rh}^{\mathrm{I}}-\mathrm{IPr}$ complexes. $^{a}$

\begin{tabular}{|c|c|c|}
\hline Entry & Complex & $\Delta \mathrm{H}^{\neq}\left(\mathrm{kcal} \cdot \mathrm{mol}^{-1}\right)$ \\
\hline 1 & $\mathrm{RhCl}(=\mathrm{CHPh})(\mathrm{IPr}) \mathrm{PPh}_{3}{ }^{15 \mathrm{~h}}$ & $13.4 \pm 0.8$ \\
\hline 2 & $\operatorname{RhCl}\left(\eta^{2}-\mathrm{CH}_{2}=\mathrm{CH}_{2}\right)(\mathrm{IPr}) \mathrm{PPh}_{3}{ }^{15 \mathrm{~h}}$ & $16.6 \pm 0.7$ \\
\hline 3 & {$\left[\mathrm{Rh}(\mu-\mathrm{Cl})(\mathrm{IPr})\left(\eta^{2}-\mathrm{CH}_{2}=\mathrm{CH}_{2}\right)\right]_{2}(\mathbf{2})^{6}$} & $11.8 \pm 0.4$ \\
\hline 4 & $\operatorname{RhCl}(\operatorname{IPr})(\mathrm{py})\left(\eta^{2}\right.$-coe $)(\mathbf{3 a})^{6}$ & $15.1 \pm 0.7$ \\
\hline 5 & $\mathrm{RhCl}(\operatorname{IPr})(\mathrm{py})\left(\eta^{2}\right.$-ethylene $)(\mathbf{3 b})^{6}$ & $14.1 \pm 0.6$ \\
\hline 6 & $\operatorname{Rh}($ acac $)(\operatorname{IPr})\left(\eta^{2}-\text { coe }\right)^{12 \mathrm{~h}}$ & $12.7 \pm 0.4$ \\
\hline 7 & $\operatorname{Rh}($ acac $)(\operatorname{IPr})\left(\eta^{2} \text {-ethylene }\right)^{12 \mathrm{~h}}$ & $10.4 \pm 0.3$ \\
\hline 8 & {$\left[\mathrm{Rh}(\mathrm{IPr})\left(\eta^{2}-\mathrm{coe}\right)\left(\mathrm{NCCH}_{3}\right)_{2}\right] \mathrm{OTf}^{12 \mathrm{~h}}$} & $12.7 \pm 0.3$ \\
\hline 9 & $\mathrm{RhCl}(\mathrm{IPr})(\mathrm{CO})(\mathrm{py})(\mathbf{1 7})$ & $10.6 \pm 0.3$ \\
\hline 10 & $\mathrm{RhCl}(\mathrm{IPr})\left(\mathrm{O}_{2}\right)(\mathrm{py})(\mathbf{1 8})$ & $9.9 \pm 0.6$ \\
\hline 11 & $\operatorname{RhCl}(\mathrm{IPr})\left(\mathrm{O}_{2}\right)(\mathrm{py})_{2}(\mathbf{1 9})$ & $13.0 \pm 0.7$ \\
\hline
\end{tabular}

\section{Charge Decomposition Analysis (CDA) on square-planar Rh-IPr-Chlorido complexes}

The relative stability observed in phosphine-pyridine derivative 12 in favour of a more hindered cis phosphine-IPr configuration indicates a notable influence of electronic factors over the whole 30 stability of the square-planar complexes. Thus, we have performed a Charge Decomposition Analysis (CDA) ${ }^{27}$ between the metallic fragment and the $\pi$-acceptor ligand in order to better explain the observed results. This method provides a deeper insight into the nature of the acceptor-donor interactions and it 35 has been extensively used to analyse the metal-ligand bonds in organometallic complexes ${ }^{28}$ according to the model of DewarChatt-Duncanson. ${ }^{29}$ In particular the method allows a measurement of the electron donation of the ligand to the metal fragment ( $\sigma$-donation) and the back-donation from the metal 40 centre to the ligand moiety ( $\pi$-backbonding) to be obtained. In our case the analysis was carried out by measuring the interaction of two distinct metal fragments [RhCl(IPr)(py)]-derived from 12a (fragment A) and 12b (fragment $B$ ) with a set of different ligands (Scheme 8, Table 2).

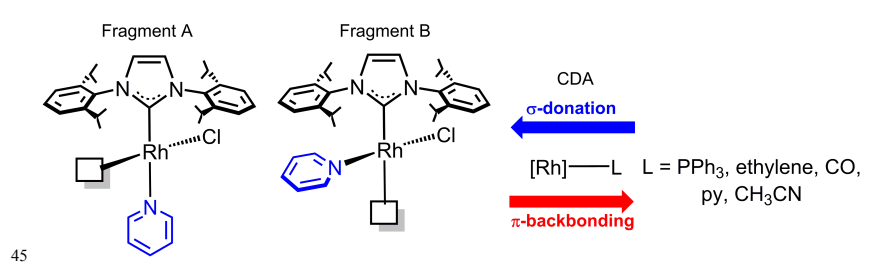

Scheme 8. CDA study of the bond between metallic fragments A and $\mathrm{B}$ with different ligands.

Table 2. CDA calculations for fragments A and B.

\begin{tabular}{|c|c|c|c|c|c|c|c|}
\hline \multirow{2}{*}{ Entry } & \multirow{2}{*}{ Ligand } & \multicolumn{3}{|c|}{ Fragment $\mathrm{A}$} & \multicolumn{3}{|c|}{ Fragment B } \\
\hline & & $\mathrm{L} \rightarrow \mathrm{Rh}^{a}$ & $\mathrm{Rh} \rightarrow \mathrm{L}$ & $\mathrm{BE}^{b}$ & $\mathrm{~L} \rightarrow \mathrm{Rh}$ & $\mathrm{Rh} \rightarrow \mathrm{L}$ & $\mathrm{BE}$ \\
\hline 1 & ethylene & 0.591 & 0.347 & 61.4 & 0.565 & 0.246 & 44.0 \\
\hline 2 & $\mathrm{CO}$ & 0.518 & 0.417 & 67.9 & 0.553 & 0.334 & 50.7 \\
\hline 3 & $\mathrm{PPh}_{3}$ & 0.396 & 0.377 & 65.0 & 0.322 & 0.176 & 49.9 \\
\hline 4 & pyridine & 0.235 & 0.124 & 40.9 & 0.251 & 0.063 & 31.9 \\
\hline 5 & $\mathrm{CH}_{3} \mathrm{CN}$ & 0.282 & 0.173 & 36.2 & 0.298 & 0.083 & 25.6 \\
\hline
\end{tabular}

Table 2 summarises the results obtained with respect to $\mathrm{L} \rightarrow$ [Rh] $\sigma$-donation, $[\mathrm{Rh}] \rightarrow \mathrm{L} \pi$-backbonding and the bonding energy between fragments A or B and the ligand. In all cases 60 bonding energy was higher for fragment A. Nevertheless, $\sigma-$ donation values are always comparable for fragments $\mathrm{A}$ and $\mathrm{B}$, thus $\pi$-backbonding values should account for the measured differences in bonding energies. Such evidence suggests that coordination in cis position to the NHC ligand allows for a more ${ }_{65}$ efficient $\pi$-backbonding and consequently, it is the favoured coordination site for $\pi$-acceptor ligands such as $\mathrm{CO}$ or $\mathrm{PPh}_{3}$ in 12a. As expected, pyridine and acetonitrile show both lower $\pi$ acceptor ability but pyridine displays slightly higher bond energy than acetonitrile, in agreement with the formation of 8-9.

70 In the analysed case CDA-analysis suggest how the M-L bond is the result of a complex series of interactions. In the case of complex 12a, CDA analysis revealed two prevalent interactions (Scheme 9). HOMO -7 represents the $\mathrm{L} \rightarrow[\mathrm{Rh}] \sigma$-donation and contributes to $10.2 \mathrm{kcal} \mathrm{mol}^{-1}$ of the total binding energy of 65.0 $75 \mathrm{kcal} \mathrm{mol}^{-1}$. It involves a donation of 0.092 electron of $0.396(23 \%$ of the total $\sigma$-donation) from $\mathrm{PPh}_{3}$ to the metallic fragment. The second most relevant interaction refers to HOMO -1 which is the one providing for a 0.126 electrons of 0.377 (34\%) of $\pi$ backbonding from $\mathrm{Rh}$ to $\mathrm{PPh}_{3}$, contributing to the total binding 80 energy with $8.2 \mathrm{Kcal} \mathrm{mol}^{-1}$. 


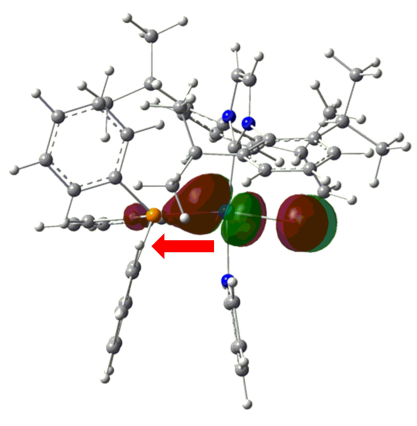

$-4.7 \mathrm{eV}$

HOMO-1

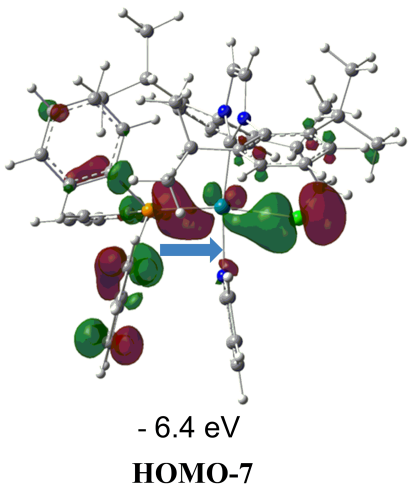

HOMO-7
Figure 8. Selected molecular orbitals with corresponding energies for complex 12a.

\section{Concluding Remarks}

5 The electronic and steric factors that control the coordination chemistry of $\mathrm{N}$-donor ligands in a $\mathrm{Rh}^{\mathrm{I}}-\mathrm{NHC}$-chlorido squareplanar framework have been disclosed. Both experimental and theoretical results indicate that pyridine shows a clear tendency to coordinate trans to IPr whereas $\pi$-acceptor ligands bind 10 preferentially cis to IPr and trans to chlorido (olefin, $\mathrm{CO}$ or $\mathrm{PPh}_{3}$ ), unless steric bulk hinders the coordination of the ligand $\left(\mathrm{PCy}_{3}\right)$. In contrast, acetonitrile binds weaker than pyridine does, but it is able to form cis-to IPr complexes. In this system ethylene forms stronger coordination bonds than coe. CDA analysis shows 15 that $\sigma$-donation values are similar for cis- or trans-IPr coordination, whereas $\pi$-backbonding is significantly increased in cis position. Molecular dioxygen displaces the labile cyclooctene ligand in these square-planar complexes to give a dioxygen adduct or a peroxo complex in function of the number of pyridine

20 ligands coordinated at the rhodium centre. The influence of ancillary ligands on the Rh-IPr rotational barrier is mainly steric in origin. However, the presence of a $\pi$-donor ligand such as chlorido, also slows down the dynamic process. The basic knowledge on coordination chemistry reported in this work is

25 being applied in our group for the design of more efficient catalysts for $\mathrm{C}-\mathrm{C}$ and $\mathrm{C}-\mathrm{X}$ couplings based on the Rh-NHC framework.

\section{Acknowledgement}

Financial support from the spanish Ministerio de Economía y ${ }_{30}$ Competitividad (MINECO/FEDER) (CTQ2013-42532-P and CONSOLIDER INGENIO CSD2009-0050 projects), the Diputación General de Aragón (DGA/FSE-E07), the ARAID Foundation under the program "Jóvenes Investigadores", and the Campus Iberus, are gratefully acknowledged. ADG thanks the 35 "subprograma de Formación Postdoctoral" from the Spanish MINECO.

\section{Experimental part}

All reactions were carried out with rigorous exclusion of air using ${ }_{40}$ Schlenck-tube techniques. Organic solvents were dried by standard procedures and distilled under argon prior to use or obtained oxygen- and water- free from a Solvent Purification System (Innovative Technologies). The starting materials $\mathbf{1},{ }^{12 \mathrm{a}} \mathbf{2},{ }^{6}$ $3 a^{6},{ }^{6} 1,^{12 a}$ and $15^{12 h}$ were prepared as previously described in the ${ }_{45}$ literature. Chemical shifts (expressed in parts per million) are referenced to residual solvent peaks $\left({ }^{1} \mathrm{H},{ }^{13} \mathrm{C}\right)$ or external $\mathrm{H}_{3} \mathrm{PO}_{4}$ $\left({ }^{31} \mathrm{P}\right), \mathrm{CFCl}_{3}\left({ }^{19} \mathrm{~F}\right)$ or liquid $\mathrm{NH}_{3}\left({ }^{15} \mathrm{~N}\right)$. Coupling constants, $J$ and $N$, are given in hertz. Spectral assignments were achieved by combination of ${ }^{1} \mathrm{H}-{ }^{1} \mathrm{H} \quad$ COSY, ${ }^{13} \mathrm{C}-\mathrm{APT}$, and ${ }^{1} \mathrm{H}-{ }^{13} \mathrm{C}$ 50 $\mathrm{HSQC} / \mathrm{HMBC}$ experiments. $\mathrm{C}, \mathrm{H}$, and $\mathrm{N}$ analyses were carried out in a Perkin-Elmer $2400 \mathrm{CHNS} / \mathrm{O}$ analyzer. Infrared spectra were recorded on a Perkin-Elmer Spectrum 100 spectrometer, using a Universal ATR Sampling Accesory (neat samples).

Reactivity of 1 or 2 with acetonitrile. A solution of 1 (100 mg, $\left.{ }_{55} 0.079 \mathrm{mmol}\right)$ or $2(100 \mathrm{mg}, 0.091 \mathrm{mmol})$ in a mixture of toluene $(2 \mathrm{~mL})$ and acetonitrile $(2 \mathrm{~mL})$ was stirred at room temperature for $3 \mathrm{~h}$. Then, the solution was concentrated to ca. $1 \mathrm{~mL}$ and $n$ hexane added to induce the precipitation of a orange solid, which was washed with $n$-hexane $(3 \times 3 \mathrm{~mL})$ and dried in vacuo, ${ }_{60}$ corresponding to the starting complex.

In-situ formation of $\mathrm{RhCl}(\mathrm{IPr})\left(\eta^{2}-\mathrm{CH}_{2}=\mathrm{CH}_{2}\right)\left(\mathrm{CH}_{3} \mathrm{CN}\right)$ (4). A solution of $2(15 \mathrm{mg}, 0.014 \mathrm{mmol})$ in toluene- $d_{8}(0.5 \mathrm{~mL}, \mathrm{NMR}$ tube) was treated with $100 \mu \mathrm{L}$ of acetonitrile. ${ }^{1} \mathrm{H}$ NMR (300 $\mathrm{MHz}$, toluene- $\left.d_{8}, 253 \mathrm{~K}\right): \delta 7.4-6.9\left(6 \mathrm{H}, \mathrm{H}_{\mathrm{Ph}}\right), 6.66(\mathrm{~s}, 2 \mathrm{H}$, ${ }_{65}=\mathrm{CHN}$ ), 3.75 and 2.77 (both sept, $J_{\mathrm{H}-\mathrm{H}}=6.5,4 \mathrm{H}, \mathrm{CHMe}_{\mathrm{IPr}}$ ), 2.47 and 2.33 (both d, $\left.J_{\mathrm{H}-\mathrm{H}}=12.3,4 \mathrm{H}, \mathrm{CH}_{2}=\mathrm{CH}_{2}\right), 2.15(\mathrm{~s}, 3 \mathrm{H}$, $\mathrm{CH}_{3} \mathrm{CN}$ ), 1.65, 1.43, 1.06, and 1.02 (all d, $J_{\mathrm{H}-\mathrm{H}}=6.5,24 \mathrm{H}$, $\left.\mathrm{CHMe}_{\text {IPr }}\right) .{ }^{13} \mathrm{C}\left\{{ }^{1} \mathrm{H}\right\}$-APT NMR $\left(75.1 \mathrm{MHz}\right.$, toluene- $\left.d_{8}, 253 \mathrm{~K}\right): \delta$ $181.4\left(\mathrm{~d}, J_{\mathrm{C}-\mathrm{Rh}}=56.7, \mathrm{Rh}-\mathrm{C}_{\mathrm{IPr}}\right), 147.7$ and 145.5 (both s, $\mathrm{C}_{\mathrm{q}-\mathrm{IPr}}$ ), $70137.2\left(\mathrm{~s}, \mathrm{C}_{\mathrm{q}} \mathrm{N}\right.$ ), 129.4, 124.3, and 123.7 (all s, $\mathrm{CH}_{\mathrm{Ph}-\mathrm{IPr}}$ ), 124.3 (s, $=\mathrm{CHN}), 118.5\left(\mathrm{~s}, \mathrm{CH}_{3} \mathrm{CN}\right), 41.8\left(\mathrm{~d}, J_{\mathrm{C}-\mathrm{Rh}}=15.4, \mathrm{CH}_{2}=\mathrm{CH}_{2}\right), 28.6$ and 28.5 (both s, $\underline{\mathrm{CHMe}} \mathrm{IPr}_{\mathrm{IPr}}$ ), 25.9, 25.7, 23.4, and 22.9 (all s, $\left.\mathrm{CHMe}_{\mathrm{IPr}}\right), 0.3$ (br, $\left.\underline{\mathrm{CH}}_{3} \mathrm{CN}\right)$.

Preparation of $\left[\mathbf{R h}(\mathrm{IPr})\left(\mathrm{CH}_{3} \mathrm{CN}\right)_{3}\right] \mathrm{Cl}$ (5). An acetonitrile 75 solution $(10 \mathrm{~mL})$ of $\mathbf{1}(100 \mathrm{mg}, 0.079 \mathrm{mmol})$ was heated at $80^{\circ} \mathrm{C}$ for $5 \mathrm{~h}$. After removing the solvent in vacuo, addition of $n$-hexane at caused the precipitation of a pale brown solid which was washed with $n$-hexane ( $3 \times 3 \mathrm{~mL})$ and dried in vacuo. ${ }^{1} \mathrm{H}$ NMR and ${ }^{13} \mathrm{C}\left\{{ }^{1} \mathrm{H}\right\}$ spectra match with that of $\left[\mathrm{Rh}(\mathrm{IPr})\left(\mathrm{CH}_{3} \mathrm{CN}\right)_{3}\right] \mathrm{OTf}$ ${ }_{80}$ described previously. ${ }^{12 \mathrm{~h}}$

Preparation of $\mathrm{RhCl}(\mathrm{IPr})\left(\boldsymbol{\eta}^{2}-\mathrm{coe}\right)\left\{\boldsymbol{\eta}^{1}-\mathrm{N}\left(\mathrm{C}_{5} \mathrm{H}_{4}\right)-\mathbf{2}-\mathrm{CH}_{2} \mathrm{CN}\right\}$ (8). An orange solution of $\mathbf{1}(300 \mathrm{mg}, 0.236 \mathrm{mmol})$ in toluene (10 $\mathrm{mL})$ was treated with 2-pyridylacetonitrile $(28 \mu \mathrm{L}, 0.25 \mathrm{mmol})$ and it was stirred at room temperature for $1 \mathrm{~h}$. Then, the solvent 85 was removed in vacuo and addition of $n$-hexane caused the precipitation of a yellow solid which was washed with $n$-hexane (3 x $3 \mathrm{~mL}$ ) and dried in vacuo. Yield: $278 \mathrm{mg}(78 \%)$. Anal. Calcd. for $\mathrm{C}_{42} \mathrm{H}_{56} \mathrm{~N}_{4} \mathrm{ClRh}$ : C, 66.79; H, 7.47; N, 7.42. Found: C, $66.93 ; \mathrm{H}, 7.52 ; \mathrm{N}, 7.48 .{ }^{1} \mathrm{H}$ NMR $\left(500 \mathrm{MHz}\right.$, toluene- $\left.d_{8}, 253 \mathrm{~K}\right)$ : ${ }_{90} \delta 8.19\left(\mathrm{~d}, J_{\mathrm{H}-\mathrm{H}}=5.1,1 \mathrm{H}, \mathrm{H}_{6-\mathrm{py}}\right), 7.3-7.0\left(\mathrm{~m}, 6 \mathrm{H}, \mathrm{H}_{\mathrm{Ph}-\mathrm{IPr}}\right), 6.46(\mathrm{dd}$, $\left.J_{\mathrm{H}-\mathrm{H}}=9.0,7.7,1 \mathrm{H}, \mathrm{H}_{4-\mathrm{py}}\right), 6.86\left(\mathrm{~d}, J_{\mathrm{H}-\mathrm{H}}=7.7,1 \mathrm{H}, \mathrm{H}_{3-\mathrm{py}}\right), 6.61$ and 6.51 (both d, $\left.J_{\mathrm{H}-\mathrm{H}}=1.7,2 \mathrm{H},=\mathrm{CHN}\right), 6.08\left(\mathrm{dd}, J_{\mathrm{H}-\mathrm{H}}=9.0,5.1\right.$, $1 \mathrm{H}, \mathrm{H}_{5-\mathrm{py}}$ ), 5.79 and 3.76 (both d, $J_{\mathrm{H}-\mathrm{H}}=20.0,2 \mathrm{H}, \mathrm{CH}_{2-\mathrm{py}}$ ), 4.66, $3.79,2.72$, and 2.02 (all sept, $\left.J_{\mathrm{H}-\mathrm{H}}=6.5,4 \mathrm{H}, \underline{\mathrm{CHMe}}_{\mathrm{IPr}}\right), 3.0(\mathrm{~m}$, ${ }_{95} 2 \mathrm{H},=\mathrm{CH}_{\text {coe }}$ ) $1.96,1.53,1.43,1.21,1.18,1.06,1.00$, and 0.84 (all $\left.\mathrm{d}, J_{\mathrm{H}-\mathrm{H}}=6.5,24 \mathrm{H}, \mathrm{CHMe}_{\mathrm{IPr}}\right), 1.6-0.3\left(\mathrm{br}, 12 \mathrm{H}, \mathrm{CH}_{2-\mathrm{coe}}\right) .{ }^{13} \mathrm{C}\left\{{ }^{1} \mathrm{H}\right\}-$ APT NMR $\left(125.6 \mathrm{MHz}\right.$, toluene- $\left.d_{8}, 253 \mathrm{~K}\right): \delta 183.3\left(\mathrm{~d}, J_{\mathrm{C}-\mathrm{Rh}}=\right.$ 54.3, Rh- $\mathrm{C}_{\mathrm{IPr}}$ ), 154.5 (s, $\mathrm{C}_{2-\mathrm{py}}$ ), 152.4 (s, $\mathrm{C}_{6-\mathrm{py}}$ ), 149.0, 148.3, 146.5, and 146.0 (all s, $\mathrm{C}_{\mathrm{q}-\mathrm{IPr}}$ ), 137.2 and 136.8 (both $\mathrm{s}, \mathrm{C}_{\mathrm{q}} \mathrm{N}$ ), 
135.8 (s, $\mathrm{C}_{4-\mathrm{py}}$ ), 130.2, 129.8, 124.6, 123.1, 122.9, and 122.6 (all $\left.\mathrm{s}, \mathrm{CH}_{\mathrm{Ph}-\mathrm{IPr}}\right), 124.4$ and $123.9(\mathrm{~s},=\mathrm{CHN}), 122.8\left(\mathrm{~s}, \mathrm{C}_{3-\mathrm{py}}\right), 121.4(\mathrm{~s}$, $\left.\mathrm{C}_{5-\mathrm{py}}\right), 117.0\left(\mathrm{CN}_{\mathrm{py}}\right), 60.0\left(\mathrm{~d}, J_{\mathrm{C}-\mathrm{Rh}}=16.6,=\mathrm{CH}_{\mathrm{coe}}\right), 52.8\left(\mathrm{~d}, J_{\mathrm{C}-\mathrm{Rh}}\right.$ $\left.=14.1,=\mathrm{CH}_{\mathrm{coe}}\right), 30.7,30.4,29.3,29.1,26.7$, and $26.5\left(\right.$ all s, $\mathrm{CH}_{2-}$ 5 coe), 29.7, 29.4, 28.6, and 28.5 (all s, $\underline{\mathrm{C}} \mathrm{HMe}_{\mathrm{IPr}}$ ), 27.7 (s, $\mathrm{CH}_{2-\mathrm{py}}$ ), 27.6, 26.8, 26.3, 26.2, 24.9, 23.1, 23.0, and 21.6 (all s, $\mathrm{CHMe}_{\mathrm{IPr}}$ ). ${ }^{15} \mathrm{~N}-{ }^{1} \mathrm{H}$ HMBC $\left(40 \mathrm{MHz}\right.$, toluene- $\left.d_{8}, 298 \mathrm{~K}\right): \delta 270.5\left(\mathrm{~N}_{\mathrm{py}}\right), 190.0$ and $189.8\left(\mathrm{~N}_{\mathrm{IPr}}\right)$.

Preparation of $\mathrm{RhCl}(\mathrm{IPr})\left(\eta^{2}-\mathrm{CH}_{2}=\mathrm{CH}_{2}\right)\left\{\eta^{1}-\mathrm{N}\left(\mathrm{C}_{5} \mathrm{H}_{4}\right)-2-\right.$ ${ }_{10} \mathrm{CH}_{2} \mathrm{CN}$ \} (9). The complex was prepared as described for 8 starting from $2(300 \mathrm{mg}, 0.270 \mathrm{mmol})$ and 2-pyridylacetonitrile (32 $\mu \mathrm{L}, 0.29 \mathrm{mmol})$. Yield: $325 \mathrm{mg}(89 \%)$. Anal. Calcd. for $\mathrm{C}_{36} \mathrm{H}_{46} \mathrm{~N}_{4} \mathrm{ClRh}: \mathrm{C}, 64.23 ; \mathrm{H}, 6.89 ; \mathrm{N}, 8.32$. Found: $\mathrm{C}, 64.56 ; \mathrm{H}$, 6.99; N, 8.38. ${ }^{1} \mathrm{H}$ NMR (500 MHz, toluene- $\left.d_{8}, 253 \mathrm{~K}\right): \delta 7.86(\mathrm{~d}$, $\left.{ }_{15} J_{\mathrm{H}-\mathrm{H}}=5.2,1 \mathrm{H}, \mathrm{H}_{6-\mathrm{py}}\right), 7.3-7.0\left(\mathrm{~m}, 6 \mathrm{H}, \mathrm{H}_{\mathrm{Ph}-\mathrm{IPr}}\right), 6.38\left(\mathrm{dd}, J_{\mathrm{H}-\mathrm{H}}=\right.$ $\left.9.2,7.5,1 \mathrm{H}, \mathrm{H}_{4-\mathrm{py}}\right), 6.75\left(\mathrm{~d}, J_{\mathrm{H}-\mathrm{H}}=7.5,1 \mathrm{H}, \mathrm{H}_{3-\mathrm{py}}\right), 6.59$ and 6.44 (both d, $\left.J_{\mathrm{H}-\mathrm{H}}=1.5,2 \mathrm{H},=\mathrm{CHN}\right), 5.95\left(\mathrm{dd}, J_{\mathrm{H}-\mathrm{H}}=9.2,5.2,1 \mathrm{H}, \mathrm{H}_{5-}\right.$ py), 4.97 and 3.98 (both d, $J_{\mathrm{H}-\mathrm{H}}=20.1,2 \mathrm{H}, \mathrm{CH}_{2-\mathrm{py}}$ ), 4.24, 3.73, 2.92, and 2.35 (all sept, $J_{\mathrm{H}-\mathrm{H}}=6.5,4 \mathrm{H}, \mathrm{CHMe}_{\mathrm{IPr}}$ ), 2.63, 2.22, 201.91 , and 1.37 (all dd, $J_{\mathrm{H}-\mathrm{H}}=11.3,8.2,4 \mathrm{H}, \mathrm{CH}_{2}=\mathrm{CH}_{2}$ ), 1.88, $1.63,1.46,1.30,1.16,1.06,1.05$, and 0.93 (all d, $J_{\mathrm{H}-\mathrm{H}}=6.5,24 \mathrm{H}$, $\left.\mathrm{CHMe}_{\text {IPr }}\right) .{ }^{13} \mathrm{C}\left\{{ }^{1} \mathrm{H}\right\}$-APT NMR (125.6 MHz, toluene- $\left.d_{8}, 253 \mathrm{~K}\right)$ : $\delta 182.8\left(\mathrm{~d}, J_{\mathrm{C}-\mathrm{Rh}}=54.2, \mathrm{Rh}-\mathrm{C}_{\mathrm{IPr}}\right), 153.7\left(\mathrm{C}_{2-\mathrm{py}}\right), 149.7\left(\mathrm{~s}, \mathrm{C}_{6-\mathrm{py}}\right)$, 149.1, 148.3, 146.4, and 145.7 (all s, $\mathrm{C}_{\mathrm{q}-\mathrm{IPr}}$ ), 137.1 and 137.0 ${ }_{25}$ (both s, $\mathrm{C}_{\mathrm{q}} \mathrm{N}$ ), 135.9 (s, $\mathrm{C}_{4-\mathrm{py}}$ ), 129.9, 129.1, 124.9, 124.4, 123.2, and 122.9 (all s, $\mathrm{CH}_{\mathrm{Ph}-\mathrm{IPr}}$ ), 124.4 and 123.9 (both s, $=\mathrm{CHN}$ ), 122.7 $\left(\mathrm{s}, \mathrm{C}_{3-\text { py }}\right), 122.5\left(\mathrm{~s}, \mathrm{C}_{5 \text {-py }}\right), 116.6\left(\mathrm{~s}, \mathrm{CN}_{\mathrm{py}}\right), 44.8\left(\mathrm{~d}, J_{\mathrm{C}-\mathrm{Rh}}=17.6\right.$, $\left.\mathrm{CH}_{2}=\mathrm{CH}_{2}\right), 37.4\left(\mathrm{~d}, J_{\mathrm{C}-\mathrm{Rh}}=15.8, \mathrm{CH}_{2}=\mathrm{CH}_{2}\right), 27.0\left(\mathrm{~s}, \mathrm{CH}_{2-\mathrm{py}}\right)$, 29.7, 29.4, 28.7, and 28.7 (all s, $\underline{\mathrm{C} H M \mathrm{IPr}_{\mathrm{IP}}}$ ), 27.3, 26.8, 26.3, 25.9, 30 24.5, 23.0, 22.9, and 22.0 (all s, $\mathrm{CHMe} \mathrm{IPr}_{\mathrm{IP}}$ ).

\section{Preparation of $\mathrm{RhCl}(\mathrm{IPr})\left\{\boldsymbol{\eta}^{1}-\mathrm{N}\left(\mathrm{C}_{5} \mathrm{H}_{4}\right)-2-\mathrm{CH}_{2} \mathrm{CN}\right\}\left\{\left(\eta^{1}-\right.\right.$}

$\left.\mathbf{N C C H}_{2}-2-\left(\mathbf{C}_{5} \mathbf{H}_{4}\right) \mathbf{N}\right\}$ (10). A solution of $\mathbf{8}(150 \mathrm{mg}, 0.198 \mathrm{mmol})$ in toluene $(10 \mathrm{~mL})$ was treated with 2-pyridylacetonitrile $(25 \mu \mathrm{L}$, $0.22 \mathrm{mmol}$ ) and was heated at $80^{\circ} \mathrm{C}$ for $3 \mathrm{~h}$. Then, the solution

35 was concentrated to ca. $1 \mathrm{~mL}$ and $n$-hexane added to induce the precipitation of a yellow solid, which was washed with $n$-hexane ( $3 \times 3 \mathrm{~mL})$ and dried in vacuo. Yield: $109 \mathrm{mg}(72 \%) .{ }^{1} \mathrm{H}$ NMR $\left(500 \mathrm{MHz}, \mathrm{C}_{6} \mathrm{D}_{6}, 298 \mathrm{~K}\right): \delta 8.34\left(\mathrm{~d}, J_{\mathrm{H}-\mathrm{H}}=4.4,1 \mathrm{H}, \mathrm{H}_{6-\mathrm{pyb}}\right), 7.59$ (br, 1H, $\mathrm{H}_{6 \text {-pya }}$ ), 7.3-7.0 (m, 6H, $\left.\mathrm{H}_{\mathrm{Ph}-\mathrm{IPr}}\right), 7.31$ (br, $\left.1 \mathrm{H}, \mathrm{H}_{3 \text {-pyb }}\right), 7.01$ $40\left(\mathrm{vt}, J_{\mathrm{H}-\mathrm{H}}=6.5,1 \mathrm{H}, \mathrm{H}_{4-\mathrm{pyb}}\right), 6.73(\mathrm{~s}, 2 \mathrm{H},=\mathrm{CHN}), 6.60\left(\mathrm{~m}, 1 \mathrm{H}, \mathrm{H}_{5-}\right.$ pyb), 6.57 (vt, $\left.J_{\mathrm{H}-\mathrm{H}}=7.7,1 \mathrm{H}, \mathrm{H}_{4-\text { pya }}\right), 6.20\left(\mathrm{br}, 1 \mathrm{H}, \mathrm{H}_{5-\text { pya }}\right), 6.01$ (d, $J_{\mathrm{H}-\mathrm{H}}=7.7,1 \mathrm{H}, \mathrm{H}_{3-\mathrm{pya}}$ ), 3.84 and 3.77 (both sept, $J_{\mathrm{H}-\mathrm{H}}=6.6,4 \mathrm{H}$, $\mathrm{CHMe}_{\mathrm{IPr}}$ ), 3.32 (br, 2H, $\mathrm{CH}_{2-\mathrm{pyb}}$ ), 2.75 and 2.67 (both d, $J_{\mathrm{H}-\mathrm{H}}=$ $10.7,2 \mathrm{H}, \mathrm{CH}_{2 \text {-pya }}$ ), 1.84 and 1.25 (both $\mathrm{d}, J_{\mathrm{H}-\mathrm{H}}=6.6,24 \mathrm{H}$, $\left.{ }_{45} \mathrm{CHMe}_{\mathrm{IPr}}\right) .{ }^{13} \mathrm{C}\left\{{ }^{1} \mathrm{H}\right\}$-APT NMR (125.6 MHz, $\left.\mathrm{C}_{6} \mathrm{D}_{6}, 298 \mathrm{~K}\right): \delta$ 173.0 (s, $\left.\mathrm{C}_{2 \text {-pya }}\right), 168.9$ (d, $\left.J_{\mathrm{C}-\mathrm{Rh}}=50.5, \mathrm{Rh}-\mathrm{C}_{\mathrm{IPr}}\right), 150.7\left(\mathrm{~s}, \mathrm{C}_{2 \text {-pyb }}\right)$, 149.5 (s, $\mathrm{C}_{6-\mathrm{pyb}}$ ), 147.7 (br, $\mathrm{C}_{\mathrm{q}-\mathrm{IPr}}$ ), 145.2 (s, $\mathrm{C}_{6 \text {-pya }}$ ), 136.8 (s, $\mathrm{C}_{4-}$ pyb), 136.7 (s, $\left.\mathrm{C}_{\mathrm{q}} \mathrm{N}\right), 134.1$ (s, $\left.\mathrm{C}_{4-\mathrm{pya}}\right), 130.5\left(\mathrm{~s}, \mathrm{C}_{\mathrm{p}-\mathrm{Ph}}\right), 124.3$ ( $\mathrm{s}$, $=\mathrm{CHN}$ ), 124.0 and 123.9 (both s, $\left.\mathrm{C}_{\mathrm{m}-\mathrm{Ph}}\right), 122.4\left(\mathrm{~s}, \mathrm{C}_{5 \text {-pyb }}\right), 122.2$ 50 (s, $\left.\mathrm{C}_{3-\text { pyb }}\right), 121.2$ (s, $\left.\mathrm{C}_{5 \text {-pya }}\right), 119.7$ (s, $\left.\mathrm{C}_{3 \text {-pya }}\right), 117.9\left(\mathrm{CN}_{\text {pyb }}\right), 116.3$ $\left(\mathrm{CN}_{\text {pya }}\right), 28.7$ and 28.5 (both s, $\left.\underline{\mathrm{CHMe}} \mathrm{IPr}\right), 26.5\left(\mathrm{~s}, \mathrm{CH}_{2 \text {-pya }}\right), 26.4$, 26.3, 23.7 and 23.6 (all s, $\mathrm{CHMe}$ IPr $), 22.8\left(\mathrm{~s}, \mathrm{CH}_{2-\mathrm{pyb}}\right) .{ }^{15} \mathrm{~N}-{ }^{1} \mathrm{H}$ HMBC (40 MHz, toluene- $\left.d_{8}, 298 \mathrm{~K}\right): \delta 315.6\left(\mathrm{~N}_{\mathrm{py}}\right), 241.9\left(\mathrm{~N}_{\mathrm{CN}}\right)$, 193.4 and $192.0\left(\mathrm{~N}_{\mathrm{IPr}}\right)$.

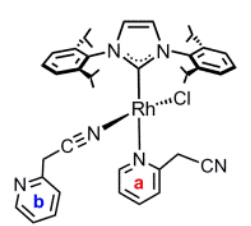

Preparation of $\mathbf{R h C l ( I P r ) ( P P h}$ )(py) (12). A solution of 11 (355 $\mathrm{mg}, 0.338 \mathrm{mmol})$ in pyridine $(5 \mathrm{~mL})$ was stirred for $20 \mathrm{~min}$ at room temperature. Then, the solution was concentrated to ca. 1 $\mathrm{mL}$ and diethyl ether added to induce the precipitation of a 60 yellow solid, which was washed with diethyl ether $(3 \times 3 \mathrm{~mL})$ and dried in vacuo. Yield: $237 \mathrm{mg}(83 \%)$. Anal. Calcd. for $\mathrm{C}_{50} \mathrm{H}_{56} \mathrm{~N}_{3} \mathrm{ClPRh}$ : C, 69.16; H, 6.50; N, 4.84. Found: C, 68.92; H, 6.67; N, 5.07. ${ }^{1} \mathrm{H}$ NMR $\left(300 \mathrm{MHz}, \mathrm{C}_{6} \mathrm{D}_{6}, 298 \mathrm{~K}\right): \delta 8.28\left(\mathrm{~d}, J_{\mathrm{H}-\mathrm{H}}\right.$ $\left.=4.2,2 \mathrm{H}, \mathrm{H}_{2-\mathrm{py}}\right), 7.5-6.7\left(23 \mathrm{H}, \mathrm{H}_{\mathrm{Ph}},=\mathrm{CHN}\right), 6.41\left(\mathrm{t}, J_{\mathrm{H}-\mathrm{H}}=7.2\right.$, $\left.{ }_{65} 1 \mathrm{H}, \mathrm{H}_{4-\mathrm{py}}\right), 5.93\left(\mathrm{dd}, J_{\mathrm{H}-\mathrm{H}}=7.2,4.2,2 \mathrm{H}, \mathrm{H}_{3-\mathrm{py}}\right), 4.11$ and 3.97 (both sept, $J_{\mathrm{H}-\mathrm{H}}=6.4,4 \mathrm{H}, \mathrm{CHMe}_{\mathrm{IPr}}$ ), 2.04, 1.31, 1.12, and 0.82 (all d, $\left.J_{\mathrm{H}-\mathrm{H}}=6.4,24 \mathrm{H}, \mathrm{CHMe}_{\mathrm{IPr}}\right) .{ }^{13} \mathrm{C}\left\{{ }^{1} \mathrm{H}\right\}$-APT NMR $(75.4$ $\left.\mathrm{MHz}, \mathrm{C}_{6} \mathrm{D}_{6}, 298 \mathrm{~K}\right): \delta 190.8\left(\mathrm{dd}, J_{\mathrm{C}-\mathrm{Rh}}=53.0, J_{\mathrm{C}-\mathrm{P}}=15.6\right.$, Rh$\mathrm{C}_{\mathrm{IPr}}$ ), 153.4 (s, $\mathrm{C}_{2-\mathrm{py}}$ ), 149.5 and 144.4 (both s, $\mathrm{C}_{\mathrm{q}-\mathrm{IPr}}$ ), 138.7 (s, $\left.{ }_{70} \mathrm{C}_{\mathrm{q}} \mathrm{N}\right), 138.1\left(\mathrm{~d}, J_{\mathrm{C}-\mathrm{P}}=35.1, \mathrm{C}_{\mathrm{q}} \mathrm{P}\right), 134.2\left(\mathrm{~d}, J_{\mathrm{C}-\mathrm{P}}=12.0, \mathrm{CH}_{o-\mathrm{PPh}}\right)$, 132.7 (s, $\mathrm{C}_{4-\mathrm{py}}$ ), 129.3, 128.5, 127.1, 124.3, and 123.1 (all s, $\mathrm{CH}_{\mathrm{Ph}}$ ), $124.0\left(\mathrm{~s},=\mathrm{CHN}\right.$ ), 121.9 (s, $\mathrm{C}_{3-\mathrm{py}}$ ), 29.3 and 28.3 (both $\mathrm{s}$, $\left.\underline{\mathrm{CHMe}}_{\mathrm{IPr}}\right), 26.7,26.6,24.2$, and 22.4 (all s, $\left.\mathrm{CHMe}_{\mathrm{IPr}}\right) .{ }^{31} \mathrm{P}\left\{{ }^{1} \mathrm{H}\right\}$ NMR $\left(121.5 \mathrm{MHz}, \mathrm{C}_{6} \mathrm{D}_{6}, 298 \mathrm{~K}\right): \delta 45.3\left(\mathrm{~d}, J_{\mathrm{P}-\mathrm{Rh}}=222.0\right)$.

75 In-situ formation of $\mathrm{RhCl}(\mathrm{IPr})\left(\mathbf{P P h}_{3}\right)\left(\mathrm{CD}_{3} \mathbf{C N}\right)(\mathbf{1 3})$. Complex $11(20 \mathrm{mg}, 0.019 \mathrm{mmol})$ was disolved in $\mathrm{CD}_{3} \mathrm{CN}(0.5 \mathrm{~mL}$, NMR tube). A mixture 70/30 13a/13b was observed. ${ }^{31} \mathrm{P}\left\{{ }^{1} \mathrm{H}\right\}$ NMR $\left(161.8 \mathrm{MHz}, \mathrm{CD}_{3} \mathrm{CN}, 298 \mathrm{~K}\right): \delta 41.9\left(\mathrm{~d}, J_{\mathrm{P}-\mathrm{Rh}}=206.7,13 \mathbf{a}\right), 22.3$ $\left(\mathrm{d}, J_{\mathrm{P}-\mathrm{Rh}}=89.4, \mathbf{1 3 b}\right)$.

${ }_{80}$ Preparation of $\left[\mathrm{Rh}(\mathrm{IPr})\left(\mathrm{PPh}_{3}\right)\left(\mathrm{CH}_{3} \mathrm{CN}\right)_{2}\right] \mathrm{OTf}$ (15). An acetonitrile solution $(5 \mathrm{~mL})$ of $\left[\mathrm{Rh}(\mathrm{IPr})\left(\mathrm{CH}_{3} \mathrm{CN}\right)_{3}\right] \mathrm{OTf}(96 \mathrm{mg}$, $0.11 \mathrm{mmol})$ was treated with $\mathrm{PPh}_{3}(29 \mathrm{mg}, 0.11 \mathrm{mmol})$. After stirring for $30 \mathrm{~min}$ at room temperature, the solution was evaporated to dryness. Addition of $n$-hexane caused the ${ }_{85}$ precipitation of a white solid which was washed $(3 \times 3 \mathrm{~mL})$ and dried in vacuo. Yield: $81 \mathrm{mg}(74 \%)$. Anal.Calcd. for $\mathrm{C}_{50} \mathrm{H}_{57} \mathrm{~N}_{4} \mathrm{SF}_{3} \mathrm{O}_{3} \mathrm{PRh}$ : C, 60.97; H, 5.83; N, 5.69. S, 3.26. Found: $\mathrm{C}, 60.73$; H, 6.29; N, 5.78; S, 3.17. ${ }^{1} \mathrm{H}$ NMR (400 MHz, $\mathrm{CD}_{3} \mathrm{CN}$, $298 \mathrm{~K}): \delta 7.8-6.9\left(\mathrm{~m}, 19 \mathrm{H}, \mathrm{H}_{\mathrm{Ph}},=\mathrm{CHN}\right), 2.85\left(\mathrm{sept}, J_{\mathrm{H}-\mathrm{H}}=6.8\right.$, ${ }_{90} 4 \mathrm{H}, \mathrm{CHMe}_{\mathrm{IPr}}$ ), 1.97 (s, 6H, $\mathrm{CH}_{3} \mathrm{CN}$ ), 1.26 and 1.17 (both d, $J_{\mathrm{H}-\mathrm{H}}$ $\left.=6.8,24 \mathrm{H}, \mathrm{CHMe}{ }_{\mathrm{IPr}}\right) .{ }^{13} \mathrm{C}\left\{{ }^{1} \mathrm{H}\right\}-\mathrm{APT}$ NMR $\left(100.4 \mathrm{MHz}, \mathrm{CD}_{3} \mathrm{CN}\right.$, $298 \mathrm{~K}): \delta 185.3\left(\mathrm{dd}, J_{\mathrm{C}-\mathrm{P}}=114.6, J_{\mathrm{C}-\mathrm{Rh}}=46.5, \mathrm{Rh}-\mathrm{C}_{\mathrm{IPr}}\right), 146.1(\mathrm{~s}$, $\left.\mathrm{C}_{\mathrm{q}-\mathrm{IPr}}\right), 136.4\left(\mathrm{~s}, \mathrm{C}_{\mathrm{q}} \mathrm{N}\right), 134.0\left(\mathrm{~d}, J_{\mathrm{C}-\mathrm{P}}=12.3, \mathrm{CH}_{o-\mathrm{PPh}}\right), 132.8(\mathrm{~d}$, $J_{\mathrm{C}-\mathrm{P}}=37.1, \mathrm{C}_{\mathrm{q}} \mathrm{P}$ ), 129.9, 128.7, 125.3, and 124.7 (both s, $\mathrm{CH}_{\mathrm{Ph}}$ ), ${ }_{95} 124.0(\mathrm{~s},=\mathrm{CHN}), 120.0\left(\mathrm{q}, J_{\mathrm{C}-\mathrm{F}}=320.0, \mathrm{CF}_{3}\right), 117.0\left(\mathrm{~s}, \mathrm{CH}_{3} \mathrm{CN}\right)$, 28.5 (s, $\mathrm{CHMe}_{\mathrm{IPr}}$ ), 25.2 and 21.9 (both s, CHMe ${ }_{\mathrm{IPr}}$ ), 0.3 (s, $\left.\mathrm{CH}_{3} \mathrm{CN}\right) .{ }^{31} \mathrm{P}\left\{{ }^{1} \mathrm{H}\right\}$ NMR $\left(161.8 \mathrm{MHz}, \mathrm{CD}_{3} \mathrm{CN}, 298 \mathrm{~K}\right): \delta 37.1$ (d, $\bar{J}_{\mathrm{P}-\mathrm{Rh}}=120.7$ ).

Preparation of $\mathrm{RhCl}(\mathrm{IPr})\left(\mathrm{PCy}_{3}\right)\left(\mathrm{CH}_{3} \mathrm{CN}\right)$ (16). An acetonitrile 100 solution $(5 \mathrm{~mL})$ of $1(100 \mathrm{mg}, 0.079 \mathrm{mmol})$ was treated with $\mathrm{PCy}_{3}(46 \mathrm{mg}, 0.172 \mathrm{mmol})$. After stirring for $30 \mathrm{~min}$ at $60{ }^{\circ} \mathrm{C}$, the solution was evaporated to dryness. Addition of $n$-hexane caused the precipitation of a pale yellow solid which was washed $(3 \times 3$ $\mathrm{mL}$ ) and dried in vacuo. Yield: $120 \mathrm{mg}(89 \%)$. Anal.Calcd. for ${ }_{105} \mathrm{C}_{47} \mathrm{H}_{72} \mathrm{~N}_{3}$ ClPRh: $\mathrm{C}, 66.53 ; \mathrm{H}, 8.55 ; \mathrm{N}, 4.95$. Found: $\mathrm{C}, 66.37 ; \mathrm{H}$, 8.46; N, 5.18. IR (pure solid, $\left.\mathrm{cm}^{-1}\right): v(\mathrm{C} \equiv \mathrm{N}) 2255(\mathrm{~W}) .{ }^{1} \mathrm{H}$ NMR $\left(400 \mathrm{MHz}, \mathrm{CD}_{3} \mathrm{CN}, 298 \mathrm{~K}\right): \delta 7.56\left(\mathrm{t}, J_{\mathrm{H}-\mathrm{H}}=7.2,2 \mathrm{H}, \mathrm{H}_{p-\mathrm{Ph}}\right), 7.43$ 
$\left(\mathrm{d}, J_{\mathrm{H}-\mathrm{H}}=7.2,4 \mathrm{H}, \mathrm{H}_{m-\mathrm{Ph}}\right), 7.42(\mathrm{~s}, 1 \mathrm{H},=\mathrm{CHN}), 2.84$ (sept, $J_{\mathrm{H}-\mathrm{H}}=$ 6.8, 4H, $\underline{\mathrm{HMe}}_{\mathrm{IPr}}$ ), 1.99 (s, 3H, $\left.\mathrm{CH}_{3} \mathrm{CN}\right), 1.9-0.9$ (m, $\left.18 \mathrm{H}, \mathrm{Cy}\right)$, 1.32 and 1.14 (both $\left.\mathrm{d}, J_{\mathrm{H}-\mathrm{H}}=6.8,24 \mathrm{H}, \mathrm{CHMe}_{\mathrm{IPr}}\right) .{ }^{13} \mathrm{C}\left\{{ }^{1} \mathrm{H}\right\}$-APT NMR (100.4 MHz, CD $\left.{ }_{3} \mathrm{CN}, 298 \mathrm{~K}\right): \delta 188.8\left(\mathrm{dd}, J_{\mathrm{C}-\mathrm{P}}=106.9, J_{\mathrm{C}-}\right.$ $\left.{ }_{5}^{5} \mathrm{Rh}=44.3, \mathrm{Rh}_{-} \mathrm{C}_{\mathrm{IPr}}\right), 146.8\left(\mathrm{~s}, \mathrm{C}_{\mathrm{q}-\mathrm{IPr}}\right), 137.7\left(\mathrm{~s}, \mathrm{C}_{\mathrm{q}} \mathrm{N}\right), 130.7$ and 126.1, (both s, $\left.\mathrm{CH}_{\mathrm{Ph}}\right), 124.6(\mathrm{~s},=\mathrm{CHN}), 118.2\left(\mathrm{~s}, \mathrm{CH}_{3} \mathrm{CN}\right), 33.0$ $\left(\mathrm{d}, J_{\mathrm{C}-\mathrm{P}}=17.1, \mathrm{PCH}\right), 30.3$ and 27.7 (both s, $\left.\mathrm{CH}_{2}\right), 29.4$ (s, $\underline{\mathrm{CHMe}}_{\mathrm{IPr}}$ ), 28.5 (d, $J_{\mathrm{C}-\mathrm{P}}=10.5, \mathrm{PCHCH}_{2}$ ), 26.3 and 22.9 (both s, $\left.\mathrm{CHMe}_{\mathrm{IPr}}\right), 1.75\left(\mathrm{~s}, \underline{\mathrm{CH}}_{3} \mathrm{CN}\right) .{ }^{31} \mathrm{P}\left\{{ }^{1} \mathrm{H}\right\} \mathrm{NMR}\left(161.8 \mathrm{MHz}, \mathrm{CD}_{3} \mathrm{CN}\right.$, $10298 \mathrm{~K}): \delta 34.6\left(\mathrm{~d}, J_{\mathrm{P}-\mathrm{Rh}}=118.8\right)$.

Preparation of $\mathrm{RhCl}(\mathrm{CO})(\mathrm{IPr})(\mathrm{py})$ (17). A yellow solution of 3a $(100 \mathrm{mg}, 0.0785 \mathrm{mmol})$ in pyridine $(10 \mathrm{~mL})$ was bubbled with $\mathrm{CO}$, while it was stirred for $15 \mathrm{~min}$ at room temperature. Then, the solution was concentrated to ca. $1 \mathrm{~mL}$ and $n$-hexane added to 15 induce the precipitation of an orange solid, which was washed with $n$-hexane $(3 \times 3 \mathrm{~mL})$ and dried in vacuo. Yield: $84 \mathrm{mg}$ (83\%). Anal. Calcd. for $\mathrm{C}_{33} \mathrm{H}_{41} \mathrm{~N}_{3} \mathrm{ClORh}$ : C, 62.51; H, 6.52; N, 6.63. Found: $\mathrm{C}, 62.43 ; \mathrm{H}, 6.47 ; \mathrm{N}, 6.77$. IR (pure solid, $\mathrm{cm}^{-1}$ ): $v(\mathrm{C}=\mathrm{O}) 1948 .{ }^{1} \mathrm{H}$ NMR $\left(300 \mathrm{MHz}, \mathrm{C}_{6} \mathrm{D}_{6}, 298 \mathrm{~K}\right): \delta 8.60\left(\mathrm{~d}, J_{\mathrm{H}-\mathrm{H}}\right.$ $\left.{ }_{20}=4.9,2 \mathrm{H}, \mathrm{H}_{2-\mathrm{py}}\right), 7.4-7.2\left(6 \mathrm{H}, \mathrm{H}_{\mathrm{Ph}}\right), 6.85(\mathrm{~s}, 2 \mathrm{H},=\mathrm{CHN}), 6.55(\mathrm{t}$, $\left.J_{\mathrm{H}-\mathrm{H}}=7.6,1 \mathrm{H}, \mathrm{H}_{4-\mathrm{py}}\right), 6.14\left(\mathrm{dd}, J_{\mathrm{H}-\mathrm{H}}=7.6,4.9,2 \mathrm{H}, \mathrm{H}_{3-\mathrm{py}}\right), 3.58$ (sept, $J_{\mathrm{H}-\mathrm{H}}=6.7,4 \mathrm{H}, \mathrm{CHMe}_{\mathrm{IPr}}$ ), 1.78 and 1.25 (both d, $J_{\mathrm{H}-\mathrm{H}}=6.7$, $\left.24 \mathrm{H}, \mathrm{CHMe}_{\mathrm{IPr}}\right) .{ }^{13} \mathrm{C}\left\{{ }^{1} \mathrm{H}\right\}$-APT NMR $\left(75.4 \mathrm{MHz}, \mathrm{C}_{6} \mathrm{D}_{6}, 298 \mathrm{~K}\right): \delta$ $187.0\left(\mathrm{~d}, J_{\mathrm{C}-\mathrm{Rh}}=82.0, \mathrm{CO}\right), 182.3\left(\mathrm{~d}, J_{\mathrm{C}-\mathrm{Rh}}=52.3, \mathrm{Rh}-\mathrm{C}_{\mathrm{IPr}}\right), 153.2$ ${ }_{25}\left(\mathrm{~s}, \mathrm{C}_{2-\mathrm{py}}\right), 149.8\left(\mathrm{~s}, \mathrm{C}_{\mathrm{q}-\mathrm{IPr}}\right), 136.9\left(\mathrm{~s}, \mathrm{C}_{\mathrm{q}} \mathrm{N}\right), 135.4\left(\mathrm{~s}, \mathrm{C}_{4-\mathrm{py}}\right), 129.9$ (s, $\mathrm{C}_{3 \text {-py }}$ ), 124.2 and 124.0 (both $\left.\mathrm{s}, \mathrm{CH}_{\mathrm{Ph}-\mathrm{Pr}}\right), 123.2$ (s, =CHN), $28.9\left(\mathrm{~s}, \mathrm{CHMe}_{\mathrm{IPr}}\right), 26.3$ and 23.1 (both d, $\left.\mathrm{CHMe}_{\mathrm{IPr}}\right)$.

Preparation of $\mathrm{RhCl}(\mathrm{IPr})\left(\mathrm{O}_{2}\right)$ (py) (18). A yellow solution of 3a $(247 \mathrm{mg}, 0.194 \mathrm{mmol})$ in toluene $(10 \mathrm{~mL})$ was bubbled with $\mathrm{O}_{2}$ 30 or air, while it was stirred for $10 \mathrm{~min}$ at room temperature. Then, the solution was concentrated to ca. $1 \mathrm{~mL}$ and $n$-hexane added to induce the precipitation of a green solid, which was washed with $n$-hexane ( $3 \times 3 \mathrm{~mL})$ and dried in vacuo. Yield: $152 \mathrm{mg}(70 \%)$. Anal.Calcd. for $\mathrm{C}_{32} \mathrm{H}_{41} \mathrm{ClN}_{3} \mathrm{O}_{2} \mathrm{Rh}$ : C, 60.24; $\mathrm{H}, 6.48 ; \mathrm{N}, 6.59$.

${ }_{35}$ Found: C, 60.12; H, 6.41; N, 6.53. IR (pure solid, $\mathrm{cm}^{-1}$ ): $v(\mathrm{O}-\mathrm{O})$ 965. ${ }^{1} \mathrm{H}$ NMR $\left(300 \mathrm{MHz}\right.$, toluene- $\left.d_{8}, 263 \mathrm{~K}\right): \delta 8.58\left(\mathrm{~d}, J_{\mathrm{H}-\mathrm{H}}=\right.$ 5.3, 2H, $\left.\mathrm{H}_{2-\mathrm{py}}\right), 7.2-7.0\left(6 \mathrm{H}, \mathrm{H}_{\mathrm{Ph}}\right), 6.73(\mathrm{~s}, 2 \mathrm{H},=\mathrm{CHN}), 6.61\left(\mathrm{t}, J_{\mathrm{H}-}\right.$ $\left.\mathrm{H}=6.4,1 \mathrm{H}, \mathrm{H}_{4-\mathrm{py}}\right), 6.27\left(\mathrm{dd}, J_{\mathrm{H}-\mathrm{H}}=6.4,5.3,2 \mathrm{H}, \mathrm{H}_{3-\mathrm{py}}\right), 3.34$ (sept, $J_{\mathrm{H}-\mathrm{H}}=6.4,4 \mathrm{H}, \mathrm{CHMe}_{\mathrm{IPr}}$ ), 1.61 and 1.17 (both d, $J_{\mathrm{H}-\mathrm{H}}=6.4$, $\left.{ }_{40} 24 \mathrm{H}, \mathrm{CHMe}_{\mathrm{IPr}}\right) .{ }^{13} \mathrm{C}\left\{{ }^{1} \mathrm{H}\right\}$-APT NMR (75.4 MHz, toluene- $d_{8}, 263$ $\mathrm{K}): \delta 167.7$ (br, Rh- $\left.\mathrm{C}_{\text {IPr }}\right), 149.5$ (s, $\left.\mathrm{C}_{2-\mathrm{py}}\right), 146.7\left(\mathrm{~s}, \mathrm{C}_{\mathrm{q}-\mathrm{IPr}}\right), 137.1$ (s, $\mathrm{C}_{\mathrm{q}} \mathrm{N}$ ), 136.1 (s, $\mathrm{C}_{4-\mathrm{py}}$ ), 129.7 and 123.4 (both s, $\mathrm{CH}_{\mathrm{Ph}-\mathrm{IPr}}$ ), 122.7 (s, $\mathrm{C}_{3-\text { py }}$ ), 28.7 (s, $\underline{\mathrm{CHMe}}_{\mathrm{IPr}}$ ), 26.3 and 23.0 (both s, $\mathrm{CHMe}_{\mathrm{IPr}}$ ).

Preparation of $\mathrm{RhCl}(\mathrm{IPr})\left(\mathrm{O}_{2}\right)(\mathrm{py})_{2}$ (19). A green solution of 18 $45(100 \mathrm{mg}, 0.157 \mathrm{mmol})$ in toluene $(10 \mathrm{~mL})$ was treated with pyridine $(130 \mu 1,0.160 \mathrm{mmol})$ and it was stirred at room temperature for $15 \mathrm{~min}$. Then, the solvent was evaporated to dryness and subsequent addition of $n$-hexane caused the precipitation of a yellow solid which was washed with $n$-hexane ${ }_{50}(3 \times 2 \mathrm{~mL})$ and dried in vacuo. Yield: $88 \mathrm{mg}(75 \%)$. Anal.Calcd. for $\mathrm{C}_{37} \mathrm{H}_{46} \mathrm{ClN}_{4} \mathrm{O}_{2} \mathrm{Rh}: \mathrm{C}, 61.97 ; \mathrm{H}, 6.47 ; \mathrm{N}, 7.81$. Found: C, 62.20; H, 6.48; N, 7.72. IR (pure solid, $\mathrm{cm}^{-1}$ ): $v(\mathrm{O}-\mathrm{O}) 879 .{ }^{1} \mathrm{H}$ NMR (400 MHz, $\mathrm{CD}_{2} \mathrm{Cl}_{2}, 298 \mathrm{~K}$ ): $\delta 8.59$ and 8.23 (both d, $J_{\mathrm{H}-\mathrm{H}}=$ $\left.5.4,4 \mathrm{H}, \mathrm{H}_{2-\mathrm{py}}\right), 7.28\left(\mathrm{t}, J_{\mathrm{H}-\mathrm{H}}=7.4,2 \mathrm{H}, \mathrm{CH}_{\mathrm{p}-\mathrm{Ph}-\mathrm{PPr}}\right), 7.49$ and 7.46 55 (both t, $\left.J_{\mathrm{H}-\mathrm{H}}=7.7,2 \mathrm{H}, \mathrm{H}_{4-\mathrm{py}}\right), 7.13\left(\mathrm{~d}, J_{\mathrm{H}-\mathrm{H}}=7.4,4 \mathrm{H}, \mathrm{CH}_{\mathrm{m}-\mathrm{Ph}-\mathrm{PPr}}\right)$, $7.06(\mathrm{~s}, 2 \mathrm{H},=\mathrm{CHN}), 7.02$ and 6.94 (both dd, $J_{\mathrm{H}-\mathrm{H}}=7.6,4.9,4 \mathrm{H}$, $\mathrm{H}_{3 \text {-py }}$ ), 3.17 (sept, $J_{\mathrm{H}-\mathrm{H}}=6.7,4 \mathrm{H}, \mathrm{CHMe}_{\mathrm{Ipr}}$ ), 1.40 and 1.10 (both $\left.\mathrm{d}, J_{\mathrm{H}-\mathrm{H}}=6.7,24 \mathrm{H}, \mathrm{CHMe}_{\mathrm{IPr}}\right){ }^{13} \mathrm{C}\left\{{ }^{1} \mathrm{H}\right\}$-APT NMR (100.6 MHz,
$\left.\mathrm{CD}_{2} \mathrm{Cl}_{2}, 298 \mathrm{~K}\right): \delta 162.4\left(\mathrm{~d}, J_{\mathrm{C}-\mathrm{Rh}}=52.09, \mathrm{Rh}-\mathrm{C}_{\mathrm{IPr}}\right), 153.0$ and 60149.5 (both s, $\left.\mathrm{C}_{2-p y}\right), 146.6$ (s, $\left.\mathrm{C}_{\text {q-IPr }}\right), 137.5\left(\mathrm{~s}, \mathrm{C}_{\mathrm{q}} \mathrm{N}\right), 136.3$ and 135.6 (both s, $\mathrm{C}_{4 \text {-py }}$ ), 129.2 and 123.0 (both s, $\mathrm{CH}_{\mathrm{Ph}-\mathrm{IPr}}$ ), 125.9 (s, $=\mathrm{CHN}), 123.0$ and $123.8\left(\mathrm{~s}, \mathrm{C}_{3-\mathrm{py}}\right), 28.6\left(\mathrm{~s}, \underline{\mathrm{CHMe}}_{\mathrm{IPr}}\right), 26.0$ and 22.5 (both d, $\mathrm{CHMe}_{\mathrm{IPr}}$ ).

Crystal Structure Determination. Single crystals for the X-ray 65 diffraction studies were grown by slow diffusion of $n$-hexane into toluene $(\mathbf{8}, \mathbf{1 8}, \mathbf{1 9})$ or benzene (12) solutions of the complexes. Xray diffraction data were collected at $100(2) \mathrm{K}$ on a Bruker APEX DUO $(\mathbf{8}, \mathbf{1 8}, \mathbf{1 9})$ or SMART APEX (12) CCD diffractometers with graphite-monochromated Mo-K $\alpha$ radiation $(\lambda=0.71073 \AA)$ 70 using narrow $\omega$ rotations $\left(0.3^{\circ}\right)$. Intensities were integrated and corrected for absorption effects with SAINT-PLUS, ${ }^{30}$ and SADABS $^{31}$ programs, both included in APEX2 package. The structures were solved by Patterson methods with SHELXS- $97^{32}$ and refined, by full matrix least-squares on $F^{2}$, with SHELXL$7597 . .^{33}$ All the structures were refined first with isotropic and later with anisotropic displacement parameters for non-disordered non$\mathrm{H}$ atoms. Specific relevant details on each structure are described below. CCDC 1035865-1035868 contain the supplementary crystallographic data for this paper.

${ }_{80}$ Crystal data for 8: $\mathrm{C}_{42} \mathrm{H}_{56} \mathrm{ClN}_{4} \mathrm{Rh} \cdot 0.5 \mathrm{C}_{6} \mathrm{H}_{14} ; M=798.39$; orange prism $0.222 \times 0.163 \times 0.108 \mathrm{~mm}^{3}$; monoclinic, $P 2_{1} / c ; a=$ 10.1831(4), $b=20.6299(9), c=19.8046(9) \AA ⿻, \beta=91.3730(10)^{\circ}$; $Z=4 ; V=4159.3(3) \AA^{3} ; D_{\mathrm{c}}=1.275 \mathrm{~g} \cdot \mathrm{cm}^{-3} ; \mu=0.510 \mathrm{~mm}^{-1} ; \min$. and max. absorption correction factors 0.834 and $0.939 ; 2 \theta_{\max }=$ ${ }_{5} 61.10^{\circ} ; 48965$ reflections collected, 11930 unique $\left(R_{\text {int }}=0.0446\right)$; number of data/restraints/parameters 11930/0/704; final GOF $1.018 ; R_{1}=0.0353(9367$ reflections, $I>2 \sigma(I))$; $\mathrm{w} R\left(F^{2}\right)=0.0875$ for all data. Two atoms in the coe ligand were observed disordered; a disorder model with two positions $(0.759$ and 90 0.241(8) occupancies) was established. Half a molecule of hexane has also been observed in the asymmetric unit. All hydrogen atoms have been observed and freely refined, except those of the solvent molecule and of the disordered atoms which were included in calculated positions and refined with a positional and ${ }_{5}$ thermal riding model.

Crystal data for 12: $\mathrm{C}_{50} \mathrm{H}_{56} \mathrm{ClN}_{3} \mathrm{PRh} \cdot 1.5 \mathrm{C}_{6} \mathrm{H}_{6} ; M=985.47$; orange prism $0.341 \times 0.222 \times 0.119 \mathrm{~mm}^{3}$; triclinic, $P-1 ; a=$ 11.6031(8), $b=12.7696(9), c=17.4596(12) \AA, \alpha=79.8850(8), \beta$ $=78.2321(8), \gamma=80.9152(8)^{\circ} ; Z=2 ; V=2473.1(3) \AA^{3} ; D_{\mathrm{c}}=$ $1001.323 \mathrm{~g} \cdot \mathrm{cm}^{-3} ; \mu=0.474 \mathrm{~mm}^{-1}$; min. and max. absorption correction factors 0.855 and $0.946 ; 2 \theta_{\max }=57.10^{\circ} ; 28870$ reflections collected, 11338 unique $\left(R_{\text {int }}=0.0231\right)$; number of data/restraints/parameters 11338/0/594; final GOF 1.076; $R_{1}=$ 0.0345 (10165 reflections, $I>2 \sigma(I))$; $\mathrm{w} R\left(F^{2}\right)=0.0806$ for all 105 data. Two solvent benzene molecules were observed in the crystal structure, the second located around a center of symmetry. Hydrogens were included in calculated positions with riding parameters.

Crystal data for 18: $\mathrm{C}_{32} \mathrm{H}_{41} \mathrm{ClN}_{3} \mathrm{O}_{2} \mathrm{Rh} ; M=638.06$; yellow prism $100.142 \times 0.065 \times 0.050 \mathrm{~mm}^{3}$; orthorhombic, Pnma; $a=$ 17.4494(10), $b=17.1900(10), c=10.1596(6) \AA ; Z=4 ; V=$ $3047.4(3) \AA^{3} ; D_{\mathrm{c}}=1.391 \mathrm{~g} \cdot \mathrm{cm}^{-3} ; \mu=0.681 \mathrm{~mm}^{-1}$; min. and max. absorption correction factors 0.857 and $0.957 ; 2 \theta_{\max }=61.08^{\circ}$; 34652 reflections collected, 4620 unique $\left(R_{\text {int }}=0.0652\right)$; number 15 of data/restraints/parameters 4620/6/296; final GOF $1.024 ; R_{1}=$ 0.0348 (2699 reflections, $I>2 \sigma(I))$; $\mathrm{w} R\left(F^{2}\right)=0.0861$ for all data. A disorder involving the chloride and the oxygen molecule was detected; eventually two positions, at both sides of the metal, were considered for each ligand $(0.616$ and $0.384(6)$ ${ }_{120}$ occupancies). All hydrogens were observed in the Fourier maps and refined as free isotropic atoms. 
Crystal data for 19: $\mathrm{C}_{37} \mathrm{H}_{46} \mathrm{ClN}_{4} \mathrm{O}_{2} \mathrm{Rh} \cdot 1.5 \mathrm{C}_{7} \mathrm{H}_{8} ; M=855.34$; orange prism $0.216 \times 0.117 \times 0.045 \mathrm{~mm}^{3}$; triclinic; $P-1 ; a=$ 10.1915(9), $\quad b=12.3169(10), \quad c=18.8266(16) \AA, \alpha=$ $76.3110(10), \beta=82.8450(10), \gamma=66.7150(10)^{\circ} ; Z=2 ; V=$ ${ }_{5} 2107.8(3) \AA^{3} ; D_{\mathrm{c}}=1.348 \mathrm{~g} \cdot \mathrm{cm}^{-3} ; \mu=0.512 \mathrm{~mm}^{-1}$; min. and max. absorption correction factors 0.897 and $0.977 ; 2 \theta_{\max }=59.28^{\circ}$; 23523 reflections collected, 10755 unique $\left(R_{\text {int }}=0.0305\right)$; number of data/restraints/parameters 10755/0/478; final GOF $1.081 ; R_{1}=$ 0.0331 (9398 reflections, $I>2 \sigma(I))$; $\mathrm{w} R\left(F^{2}\right)=0.0831$ for all data.

${ }_{10}$ Hydrogens were included in calculated positions and refined with a common riding model. A clear toluene solvent molecule was observed in the crystal structure, its constrained hydrogen atoms were also included in the structure. At this stage, six intense residuals were observed around a center of symmetry; its planar 15 disposition, together with their relative electron density, suggested and additional highly disordered half molecule of toluene (SQUEEZE evaluation: void of $177 \AA^{3}$, electron density of $56 \mathrm{e}^{-}$). Eventually, the contribution of this disordered molecule was extracted from the structure factor list using SQUEEZE 20 program. $^{34}$

Computational details. All calculations were performed with the Gaussian09 package ${ }^{35}$ at the M06 level. ${ }^{36}$ Rhodium was represented by the relativistic effective core potential (RECP) from the Stuttgart group and the associated basis set (SDD ${ }_{25}$ keyword in Gaussian 09). ${ }^{37}$ The 6-31G(d) basis set was used for all the other atoms. ${ }^{38}$ Full optimizations of geometry without any constraint were performed, followed by analytical computation of the Hessian matrix to confirm the nature of the stationary points as minima on the potential energy surface. In the Table XX we 30 have reported the computational results including the cartesian coordinates (in $\AA$ ), absolute energy (in a.u) and graphical representation including selected geometrical parameters. Charge decomposition analysis (CDA) have been performed using Dapprich and Frenking's CDA 2.2 program $^{39}$ using the same 35 methods as in the Gaussian calculations.

Determination of rotational barriers. Full line-shape analysis of the dynamic ${ }^{1} \mathrm{H}$ NMR spectra of 17,18 and 19 were carried out using the program gNMR (Cherwell Scientific Publishing Limited). The transverse relaxation time, $T_{2}$, was estimated at the 40 lowest temperature. Activation parameters $\Delta \mathrm{H}^{*}$ and $\Delta \mathrm{S}^{*}$ were obtained by linear least-squares fit of the Eyring plot. Errors were computed by published methods. ${ }^{40}$

\section{Address}

${ }^{\star}$ Departamento de Química Inórganica-Instituto de Síntesis Química y

${ }_{45}$ Catálisis Homogénea (ISQCH), Universidad de Zaragoza-CSIC, C/

Pedro Cerbuna 12, Zaragoza, 50009, Spain.

E-mail: rcastar@unizar.es

$\dagger$ Center for Refining \& Petrochemicals King Fahd University of

Petroleum \& Minerals, Dhahran, 31261, Saudi Arabia.

50 Electronic Supplementary Information (ESI) available: Cartesian coordinates and energy values for DFT calculated complexes. CCDC 1035865-1035868.

\section{References}

1 (a) K. M. Engle, D.-H. Wang, J.-Q. Yu, J. Am. Chem. Soc. 2010, 55 132, 14137; (b) I. D. Gridnev, M. Watanabe, H. Huang, T. Ikariya, T. J. Am. Chem. Soc. 2010, 132, 16637; (c) B. Gnanaprakasan, J. Zhang, D. Milstein, Angew. Chem. Int. Ed. 2010, 49, 1468; (d) C. GonzálezRodríguez, R. J. Pawley, A. B. Chaplin, A. N. Thompson, A. S
Weller, M. C. Willis, Angew. Chem. Int. Ed. 2011, 50, 5134; (e) S. T. 60 Madrahimov, J. F. Hartwig, J. Am. Chem. Soc. 2012, 134, 8136; $(f)$ B. K. Keitz, K. Endo, P. R. Patel, M. B. Herbert, R. H. Grubbs, J. Am. Chem. Soc. 2012, 134, 8136; ( $g$ ) H. Teller, M. Corbet, L. Mantilli, G. Gopukumar, R. Goddard, W. Thiel, A. Fürstner, J. Am. Chem. Soc. 2012, 134, 15331; (h) I. A. Sanhueza, A. M. Wagner, M. 65 S. Sanford, F. Schoenebeck, Chem. Sci. 2013, 4, 2767; (i) R. K. M. Khan, S. Torker, A. M. Hoveyda J. Am. Chem. Soc. 2014, 136, 14337.

2 (a) C. J. Elsevier, J. Reedijk, P. H. Walton, M. D. Ward, Dalton Trans. 2003, 1869; (b) R. H. Crabtree, New J. Chem. 2011, 35, 18; (c) A. L. Noffke, A. Habtemariam, A. M. Pizarro, P. J. Sadler, Chem. Commun. 2012, 48, 5219.

3 (a) W. A. Herrmann, Angew. Chem. Int. Ed. 2002, 41, 1290; (b) E. A. B. Kantchev, C. J. O'Brien, M. G. Organ, Angew. Chem. Int. Ed. 2007, 46, 2768; (c) J. M. Praetorius, C. M. Crudden, Dalton Trans. 2008, 4079; (d) A. J. Arduengo III, L. I. Iconaru, Dalton Trans. 2009, 6903; (e) O. Schuster, L. Yang, H. G. Raubenheimer, M. Albrecht Chem. Rev. 2009, 109, 3445; $(f)$ S. Díez-González, N. Marion, S. P. Nolan, Chem. Rev. 2009, 109, 3612; ( $g$ ) R. Visbal, M. C. Gimeno, Chem. Soc. Rev. 2014, 43, 3551; (h) M. N. Hopkinson, C. Richter, M. Schedler F. Glorius, Nature 2014, 510, 485; (i) J. A. Mata, F. E. Hahn, E. Peris, Chem. Sci. 2014, 5, 1723.

4 (a) X. Hu, Y. Tang, P. Gantzel, K. Meyer, Organometallics 2003, 22, 612; (b) D. Nemcsok, K. Wichmann, G. Frenking, Organometallics 2004, 23, 3640; (c) L. Mercs, G. Labat, A. Neels, A. Ehlers, M. 85 Albrecht, Organometallics 2006, 25, 5648; (d) D. M. Khramov, V. M. Lynch, C. W. Bielawski, Organometallics 2007, 26, 6042; (e) H. Jacobsen, A. Correa, A. Poater, C. Costabile, L. Cavallo, Coord. Chem. Rev. 2009, 253, 687; (f) A. Comas-Vives, J. N. Harvey, Eur. J. Inorg. Chem. 2011, 5025; (g) M. Alcarazo, Dalton Trans. 2011, 40, 1839; (h) D. J. Nelson, S. P. Nolan Chem. Soc. Rev. 2013, 42, 6723.

5 (a) S. Würtz, F. Glorius, Acc. Chem. Res. 2008, 41, 1523; (b) A. R. Chianese, A. Mo, D. Datta, Organometallics 2009, 28, 465; (c) H. Clavier, S. P. Nolan, Chem. Commun. 2010, 46, 841; (d) B. R. Dible, R. E. Cowley, P. L. Holland, Organometallics 2011, 30, 5123; (e), M. Teci, E. Brenner, D. Matt, L. Toupet, Eur. J. Inorg. Chem. 2013, 2841; (f) S. Dierick, D. F. Dewez, I. E. Markó, Organometallics 2014, 33, 677; (g) N. Phillips, R. Tirfoin, S. Aldridge Chem. Eur. J. 2014, 20,3825

6 A. Di Giuseppe, R. Castarlenas, J. J. Pérez-Torrente, M. Crucianelli, 100 V. Polo, R. Sancho, F. J. Lahoz, L. A. Oro, J. Am. Chem. Soc. 2012, 134, 8171 .

7 (a) I. P. Beletskaya, V. P. Ananikov, Chem. Rev. 2011, 111, 1596; (b) R. Castarlenas, A. Di Giuseppe, J. J. Pérez-Torrente, L. A. Oro, Angew. Chem. Int. Ed. 2013, 52, 213.

1058 (a) D. J. Berrisford, C. Bolm, K. B. Sharpless, Angew. Chem. Int. Ed. Engl. 1995, 34, 1059; (b) C. C. Romão, F. E. Kühn, W. A. Herrmann, Chem. Rev. 1997, 97, 3197; (c) E. M. Vog1, H. Gröger, M. Shibasaki Angew. Chem. Int. Ed. 1999, 38, 1570; (d) T. Nishimura, T. Onoue, K. Ohe, S. Uemura, J. Org. Chem. 1999, 64, 6750; (e) E. M. Ferreira, B. M. Stoltz, J. Am. Chem. Soc. 2003, 125, 9578; (f) I. Kamiya, E. Nishinaka, A. Ogawa, J. Org. Chem. 2005, 70, 696; (g) J. Nasielski, N. Hadei, G. Achonduh, E. A. B. Kantchev, C. J. O’Brien, A. Lough, M. G. Organ, Chem. Eur. J. 2010, 16, 10844; (h) A. J. Pardey, C. Longo, Coord. Chem. Rev. 2010, 254, 254; (i) S. R. Neufeldt, M. S. Sanford, Acc. Chem. Res. 2012, 45, 936; (j) M. D. Kärkäs, T. Åkermark, H. Chen, J. Sun, B. Åkermark, Angew. Chem. Int. Ed. 2013, 52, 4189 .

9 A NMR tube charged with $0.005 \mathrm{mmol}$ of $\left[\mathrm{Rh}(\mu-\mathrm{Cl})\left(\eta^{2} \text {-coe }\right)(\mathrm{IPr})\right]_{2}$ were treated with $0.1 \mathrm{mmol}$ of $\mathrm{CH}_{3} \mathrm{CN}, 0.5 \mathrm{mmol}$ of tiophenol and $0.5 \mathrm{mmol}$ of phenylacetylene. After $16 \mathrm{~h}$ at room temperature a ratio 56:44 branched/linear vinyl sulfide were obtained.

10 (a) L. Mercs, A. Neels, H. Stoeckli-Evans, M. Albrecht, Dalton Trans. 2009, 7168; (b) J. M. Smith., J. R. Long, Inorg.Chem. 2010, 49, 11223; (c) C. S. Vogel, F. W. Heinemann, M. M. Kushniyarov, K. Meyer, Inorg.Chim. Acta 2010, 364, 226.

11 (a) P. de Frémont, N. Marion, S. P. Nolan, J. Organomet. Chem. 2009, 694, 551; (b) C. C. Ho, S. Chatterjee, T.-L. Wu, K.-T. Chang, T.-H. Hsiao, H. M. Lee, Organometallics 2009, 28, 2837; (c) W. W. 
N. O, A. J. Lough, R. H. Morris, Chem. Commun. 2010, 8240. (d) J. C. Bernhammer, H. V. Huynh, Organometallics 2012, 31, 5121

12 (a) X.-Y. Yu, B. O. Patrick, B. R. James, Organometallics 2006, 25 , 4870; (b) X.-Y. Yu, H. Sun, B. O. Patrick, B. R. James, Eur. J. Inorg Chem. 2009, 1752; (c) A. Di Giuseppe, R. Castarlenas, J. J. PérezTorrente, F. J. Lahoz, V. Polo, L. A. Oro, Angew. Chem. Int. Ed. 2011, 50, 3938; (d) O. V. Zenkina, E. C. Keske, R. Wang, C. M. Crudden, Angew. Chem. Int. Ed. 2011, 50, 8100; (e) O. V. Zenkina, E. C. Keske, R. Wang, C. M. Crudden, Organometallics 2011, 30, 6423; (f) O. V. Zenkina, E. C. Keske, G. S. Kochhar, R. Wang, C. M. Crudden, Dalton Trans. 2013, 42, 2282; ( $g$ ) R. Azpíroz, A. Di Giuseppe, R. Castarlenas, J. J. Pérez-Torrente, L. A. Oro, Chem. Eur. J. 2013, 19, 3812; (h) L. Palacios, A. Di Giuseppe, A. Opalinska R. Castarlenas, J. J. Pérez-Torrente, F. J. Lahoz, L. A. Oro, Organometallics 2013, 32, 2768; (i) L. Rubio-Pérez, R. Azpíroz, A. Di Giuseppe, V. Polo, R. Castarlenas, J. J. Pérez-Torrente, L. A. Oro Chem. Eur. J. 2013, 19, 15304; (j) L. Palacios, M. J. Artigas; V. Polo, F. J. Lahoz, R. Castarlenas, J. J. Pérez-Torrente, L. A. Oro, ACS Catal. 2013, 3, 2910; (k) A. Di Giuseppe, R. Castarlenas, J. J. Pérez-Torrente, F. J. Lahoz, L. A. Oro, Chem. Eur. J. 2014, 20, 8391; (l) R. Azpíroz, L. Rubio-Pérez, A. Di Giuseppe, V. Passarelli, F. J. Lahoz, R. Castarlenas, J. J. Pérez-Torrente, L. A. Oro, ACS Catal. 2014, 4, 4244

13 C. E. Willans, K. M. Anderson, M. J. Paterson, P. C. Junk, L. J. Barbour, J. W. Steed, Eur. J. Inor. Chem. 2009, 2835

14 (a) P. H. M. Budzelaar, M. M. P. Moonen, R. de Gelder, J. M. M. Smits, A. W. Gal, Eur. J. Inor. Chem. 2000, 753. (b) G. Canepa, C. D. Brandt, H. Werner, J. Am. Chem. Soc. 2002, 124, 9666.

15 (a) A. R. Chianese, X. Li, M. C. Janzen, J. W. Faller, R. H. Crabtree, Organometallics 2003, 22, 1663; (b) S. Burling, S. Douglas, M. F. Mahon, D. Nama, P. S. Pregosin, M. K. Whittlesey, Organometallics 2006, 25, 2642; (c) V. Ritleng, C. Barth, E.. Brenner, S. Milosevic, S., M. J. Chetcuti, Organometallics 2008, 42, 4223; (d) M. M. Gallagher, A. D. Rooney, J. J. Rooney, J. Organomet. Chem. 2008, 693, 1252; (e) S. Leuthäußer, V. Schmidts, C. M. Thiele, H. Plenio, Chem. Eur. J. 2008, 14, 5465; (f) C. L. Vélez, P. R. L. Markwick, R. L. Holland, A. G. DiPasquale, A. L. Rheingold, J. M. O'Connor, Organometallics 2010, 29, 6695; (g) F. Ragone, A. Poater, L. Cavallo, J. Am. Chem. Soc. 2010, 132, 4249; (h) L. Busetto, M. C. Cassani, C. Femoni, M. Mancinelli, A. Mazzanti, R. Mazzoni, G. Solinas, Organometallics 2011, 30, 5258; (i) L. Palacios, X. Miao, A. Di Giuseppe, S. Pascal, C. Cunchillos, R. Castarlenas, J. J. PérezTorrente, F. J. Lahoz, P. H. Dixneuf, L. A. Oro, Organometallics $2011, \mathbf{3 0}, 5208$.

4516 T. T. To, C. E. Barnes, T. J. Burkey, Organometallics, 2004, 23, 2708.

17 (a) B. T. Heaton, J. A. Iggo, C. Jacob, J. Nadarajah, M. A. Fontaine, R. Messere, A. F. Noels, J. Chem. Soc., Dalton Trans. 1994, 2875; (b) L. Carlton, Magn. Reson. Chem. 2004, 42, 760; (c) S. P. Reade, D. Nama, M. F. Mahon, P. S. Pregosin, M. K. Whittlesey, Organometallics 2007, 26, 3484 .

18 For an example of $\mathrm{Rh}^{1}$-pyridine square-planar complex with mutually cis $\mathrm{PPh}_{3}$ see: P. Marcé, C. Godard, M. Feliz, X. Yáñez, C. Bo, S. Castillón, Organometallics 2009, 28, 2976.

5519 For an example of a square-planar complex with phosphine and pyridine $c i s$ to NHC see: N. Tsoureas, A. A. Danopoulos, A. A. D. Tulloch, M. E. Light, Organometallics, 2003, 22, 4750.

20 T. Leyssens, D. Peeters, A. G. Orpen, J. N. Harvey, Organometallics, 2007, 26, 2637.

6021 M. V. Baker, D. H. Brown, R. A. Haque, P. V. Simpson, B. W. Skelton, A. H. White, C. C. Williams, Organometallics, 2009, 28, 3793.

22 (a) B. Çetinkaya, P. B. Hitchcock, M. F. Lappert, D. B. Shaw, K. Spyropoulos, N. J. V. Warhurst, J. Organomet. Chem. 1993, 459, 311; (b) W. A. Herrmann, J. Fischer, K. Öfele, G. R. J. Artus, J. Organomet. Chem. 1997, 530, 259; (c) J. M. Praetorius, R. Wang, C. M. Crudden, Eur. J. Inorg. Chem. 2009, 1746.

23 E. C. Keske, O. V. Zenkina, A. Asadi, H. Sun, J. M. Praetorius, D. P Allen, D. Covelli, B. O. Patrick, R. Wang, P. Kennepohl, B. R. James, C. M. Crudden, Dalton Trans. 2013, 42, 7414.
24 (a) J. M. Praetorius, D. P. Allen, R. Wang, J. D. Webb, F. Grein, P. Kennepohl, C. M. Crudden, J. Am. Chem. Soc. 2008, 130, 3724; (b) C. M. Frech, L. J. W. Shimon, D. Milstein, Helv. Chim. Acta 2006, 89, 1730; (c) A. Y. Verat, H. Fan, M. Pink, Y. S. Chen, K. G. Caulton, Chem. Eur. J. 2008, 14, 7680.

25 (a) Y. Takahashi, M. Hashimoto, S. Hikichi, M. Akita, Y. Moro-Oka, Angew. Chem. Int. Ed. 1999, 38, 3074; (b) M. Ahijado, T. Braun, D. Noveski, N. Kocher, B. Neumann, D. Stalke, H.-G. Stammler, Angew. Chem. Int. Ed. 2005, 44, 6947; (c) G. Meier, T. Braun, Angew. Chem. Int. Ed. 2011, 50, 3280; (d) J. Cipot-Wechsler, D. Covelli, J. M. Praetorius, N. Hearns, O. V. Zenkina, E. C. Keske, R. Wang, P. Kennepohl, C. M. Crudden, Organometallics 2012, 31, 7306.

26 (a) C. D. Abernethy, G. M. Codd, M. D. Spicer, M. K. Taylor, J. Am Chem. Soc. 2003, 125, 1128; (b) K. Miqueu, E. Despagnet-Ayoub, P. W. Dyer, D. Bourissou, G. Bertrand, Chem. Eur. J. 2003, 9, 5858; (c) B. M. Gardner, J. McMaster, S. T. Liddle, Dalton Trans. 2009, 6924; (d) B.-L. Lin, P. Kang, T. D. P. Stack, Organometallics, 2010, 29, 3683.

9027 S. Dapprich, G. Frenking, J. Phys. Chem., 1995, 99, 9352.

28 (a) G. Frenking, K. Wichmann, N. Fröhlich, C. Loschen, M. Lein, J. Frunzke, V. M. Rayón, Coord. Chem. Rev. 2003, 238-239, 55; (b) P. Parameswaran, G. Frenking, Chem. Eur. J. 2009, 35, 8807; (c) Y. Tulchinsky, M. A. Iron, M. Botoshansky and M. Gandelman, Nat. 95 Chem. 2011, 3, 525. (d) A. C. Tsipis, G. N. Gkekas, Dalton Trans. 2013, 42, 8307.

29 J. S. Dewar, Bull. Soc. Chim. Fr. 1951, 18, c79; (b) J. Chatt, L. A. Duncanson, J. Chem. Soc. 1953, 2939.

30 SAINT-PLUS, version 6.01, Bruker AXS, Inc., Madison, USA, 2001.

10031 G. M. Sheldrick, SADABS, University of Göttingen, Göttingen, Germany, 1999

32 (a) G. M. Sheldrick, Acta Crystallogr., Sect. A: Fundam. Crystallogr., 1990, 46, 467-473; (b) G. M. Sheldrick, Methods Enzymol., 1997, 276, 628-641.

10533 G. M. Sheldrick, Acta Crystallogr., Sect. A: Fundam. Crystallogr., 2008, 64, 112-122.

34 SQUEEZE Program, P. v.d. Sluis, A. L. Spek, Acta Crystallogr., Sect A: Fundam. Crystallogr., 1990, 46, 194-201.

35 Gaussian 09, Revision A.1, M. J. Frisch, G. W. Trucks, H. B. Schlegel, G. E. Scuseria, M. A. Robb, J. R. Cheeseman, G. Scalmani, V. Barone, B. Mennucci, G. A. Petersson, H. Nakatsuji, M. Caricato, X. Li, H. P. Hratchian, A. F. Izmaylov, J. Bloino, G. Zheng, J. L. Sonnenberg, M. Hada, M. Ehara, K. Toyota, R. Fukuda, J. Hasegawa, M. Ishida, T. Nakajima, Y. Honda, O. Kitao, H. Nakai, T. Vreven, J. A. Montgomery, Jr., J. E. Peralta, F. Ogliaro, M. Bearpark, J. J. Heyd, E. Brothers, K. N. Kudin, V. N. Staroverov, R. Kobayashi, J. Normand, K. Raghavachari, A. Rendell, J. C. Burant, S. S. Iyengar, J. Tomasi, M. Cossi, N. Rega, J. M. Millam, M. Klene, J. E. Knox, J. B. Cross, V. Bakken, C. Adamo, J. Jaramillo, R. Gomperts, R. E. Stratmann, O. Yazyev, A. J. Austin, R. Cammi, C. Pomelli, J. W. Ochterski, R. L. Martin, K. Morokuma, V. G. Zakrzewski, G. A. Voth, P. Salvador, J. J. Dannenberg, S. Dapprich, A. D. Daniels, Ö. Farkas, J. B. Foresman, J. V. Ortiz, J. Cioslowski, and D. J. Fox, Gaussian, Inc., Wallingford CT, 2009.

12536 Y. Zhao, D. G. Truhlar, Theor. Chem. Acc. 2008, 120, 215.

37 D. Andrae, U. Haeussermann, M. Dolg, H. Stoll, H. Preuss, Theor. Chim. Acta 1990, 77, 123.

38 P. C. Hariharan, J. A. Pople, Theor. Chim. Acta 1973, 28, 213.

39 CDA 2.2, S. Dapprich, G. Frenking, M. von Hopffgarten, PhilippsUniversität Marburg, 2013. This program is free avaible: http://www.uni-marburg.de/fb15/ag-frenking/cda_g03g09.

40 P. M. Morse, M. O. Spencer, S. R. Wilson, G. S. Girolami, Organometallics 1994, 13, 1646. 